RECEIVED

Annual Technical Report

$\therefore$ Submitted 4/92

MAR 141996

OSTI

(524335)

DOE/ER

Grant No: FG03-868R60479

Response of a Tundra Ecosystem to Elevated Atmospheric Carbon

Dioxide and $\mathrm{CO}_{2}$-Induced

Climate Change

A Renewal Research Proposal

Presented to:

U.S. Department of Energy Office of Health and Environmental Research

Presented by:

San Diego State University Foundation San Diego, CA 92182

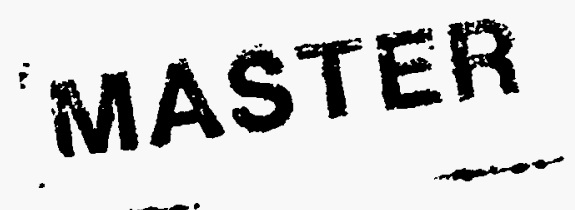

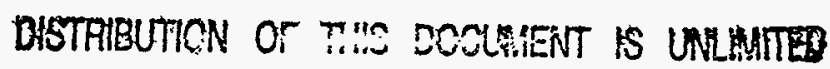


A Renewal Research Proposal

\section{Response of a Tundra Ecosystem to Elevated Atmospheric Carbon Dioxide and CO2-Induced Climate Change}

For the period:

September 1, 1992-August 31, 1995

Submitted to:

U.S. Department of Energy

Office of Health and Environmental Research

Submitted by:

San Diego State University Foundation

San Diego, California 92182-1900

Walter C. Oechel

Principal Investigator

Department of Biology

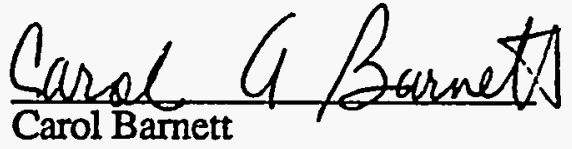

Chairman

Department of Biology

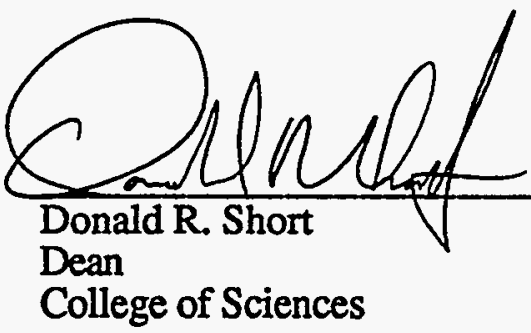

Lawrence Feinberg Associate Dean

Graduate Division and Research 
Report

$9 / 1 / 91-8 / 31 / 92$

A Renewal Research Proposal

Grant:

DE-FG03-86ER

60479

\section{Response of a Tundra Ecosystem to Elevated Atmospheric Carbon Dioxide and CO2-Induced Climate Change}

For the period:

September 1, 1992-August 31, 1995

Submitted to:

U.S. Department of Energy

Office of Health and Environmental Research

Submitted by:

San Diego State University Foundation

San Diego, California 92182-1900

Walter C. Oechel

Principal Investigator

Department of Biology

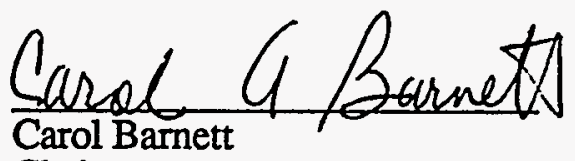

Chairman

Department of Biology
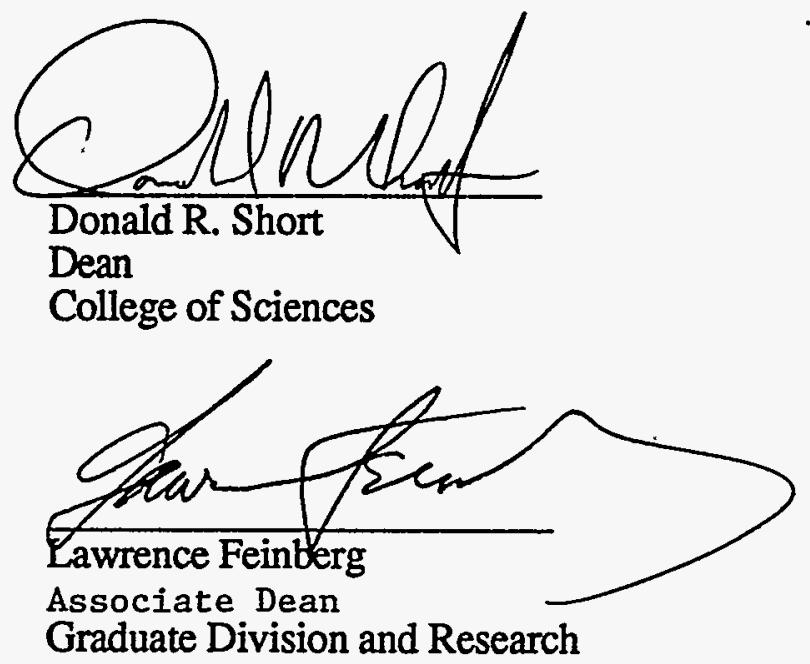


\section{TABLE OF CONTENTS}

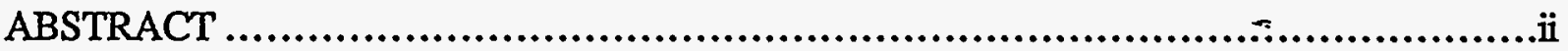

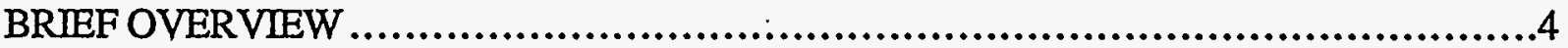

OBJECTIVES AND GENERAL HYPOTHESIS ...................................... 15

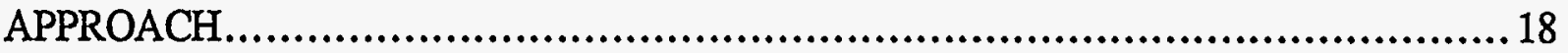

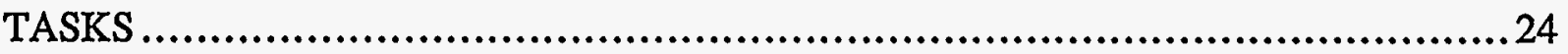

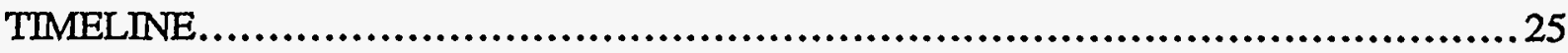

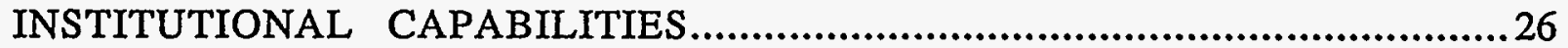

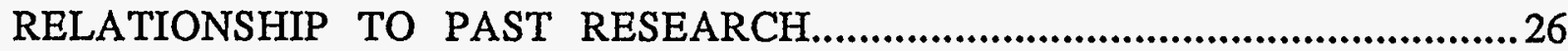

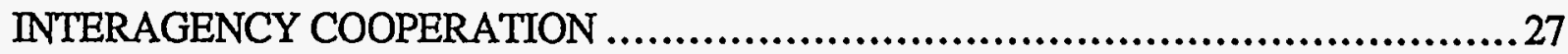

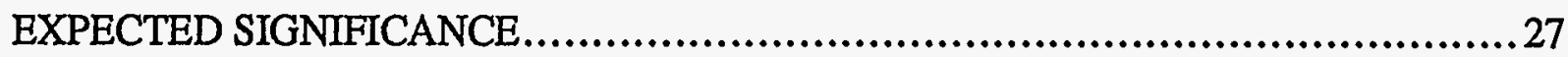

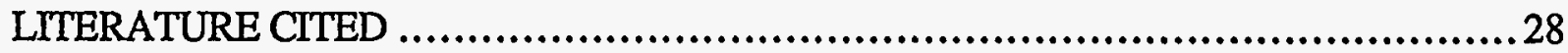

CURRENT AND PENDING SUPPORT.........................................................

BUDGETS AND BUDGET JUSTIFICATION...............................................

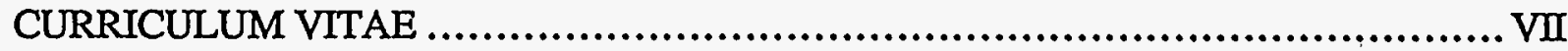

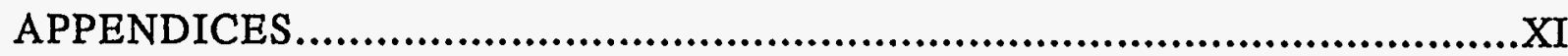

I. List of Publications, Abstracts, and Presentations....................................XII

II. Russian Research Sites and Cooperators ...................................XVII

A. Description of Research Sites and Maps

B. Letter of Support

C. GIS and Data Base for Taymyr Peninsula

III. NSF LAII ARCSS Cooperative Proposal with DOE

IV. Progress Report
A. Summary of Research Progress
B. List of Recent Publications, Abstracts, and Presentations
C. Recent Publications and Manuscripts 


\section{ABSTRACT}

Northern ecosystems contain up to $455 \mathrm{Gt}$ of $\mathrm{C}$ in the soil active layer and upper permafrost. The soil carbon in these layers is equivalent to approximately $60 \%$ of the carbon currently in the atmosphere as $\mathrm{CO}_{2}$. Much of this carbon is stored in the soil as dead organic matter. Its fate is subject to the net effects of global change on the plant and soil systems of northern ecosystems. The arctic alone contains about $60 \mathrm{Gt} \mathrm{C,90 \%} \mathrm{of} \mathrm{which} \mathrm{is} \mathrm{present} \mathrm{in} \mathrm{the} \mathrm{soil}$ active layer and upper permafrost. The arctic is assumed to have been a sink for $\mathrm{CO}_{2}$ during the historic and recent geologic past. The arctic has the potential to be a very large, long-term source or sink of $\mathrm{CO}_{2}$ with respect to the atmosphere.

In situ experimental manipulations of atmospheric $\mathrm{CO}_{2}$, indicated that there is little effect of elevated atmospheric $\mathrm{CO}_{2}$ on leaf level photosynthesis (Tissue and Oechel, 1987) or wholeecosystem $\mathrm{CO}_{2}$ flux (Oechel and Billings, 1992; Oechel et al., submitted) over the course of weeks to years, respectively. However, there may be longer-term ecosystem responses to elevated $\mathrm{CO}_{2}$ that could ultimately affect ecosystem $\mathrm{CO}_{2}$ balance (Oechel and Billings, 1992). In addition to atmospheric $\mathrm{CO}_{2}$, climate may affect net ecosystem carbon balance.

Recent results indicate that the arctic has become a source of $\mathrm{CO}_{2}$ to the atmosphere. This change coincides with recent climatic variation in the arctic, and suggests a positive feedback of arctic ecosystems on atmospheric $\mathrm{CO}_{2}$ and global change. Measurements along a latitudinal gradient across the north slope of Alaska indicate a loss of carbon from tussock tundra of $156 \mathrm{~g}$ $\mathrm{m}^{-2} \mathrm{y}^{-1}$, and from the wet tundra of $34 \mathrm{~g} \mathrm{~m}^{-2} \mathrm{y}^{-1}$. If these rates are representative of the circumpolar tundra, then they equate to a net annual global loss of carbon as $\mathrm{CO}_{2}$ to the atmosphere of $0.17 \mathrm{Gt} \mathrm{C,} 0.14 \mathrm{Gt}$ from tussock tundra, and $0.03 \mathrm{Gt}$ from wet coastal tundra.

Depending on the nature, rate, and magnitude of global environmental change, the arctic may have a positive or negative feedback on global change. At present, the initial response of the arctic indicates a net loss of carbon to the atmosphere which could result in a positive feedback on atmospheric $\mathrm{CO}_{2}$ concentration and greenhouse warming. There are obvious potential errors in scaling plot level measurements to landscape, mesoscale, and global spatial scales.

The research proposed in this application has four principal aspects: A) Long-term response of arctic plants and ecosystems to elevated atmospheric
$\mathrm{CO}_{2}$.

B) Circumpolar patterns of net ecosystem $\mathrm{CO}_{2}$ flux.

C) In situ controls by temperature and moisture on net ecosystem $\mathrm{CO}_{2}$ flux.

D) Scaling of $\mathrm{CO}_{2}$ flux from plot, to landscape, to regional scales (In conjunction with research proposed for NSF support).

In Iceland, we will evaluate the long-term (hundreds to thousands of years) effect of atmospheric $\mathrm{CO}_{2}$ enrichment from cold, $\mathrm{CO}_{2}$-rich springs on plant photosynthesis, ecosystem $\mathrm{CO}_{2}$ flux, and community composition and structure.

$\mathrm{CO}_{2}$ flux estimates at a circumpolar scale will be initiated with research in the Russian arctic and Iceland (measurements in Iceland will be obtained in the process of determining the long-term effect of elevated $\mathrm{CO}_{2}$ on arctic ecosystems). 
Temperature and moisture will be manipulated in the field to determine their effects on net ecosystem $\mathrm{CO}_{2}$ flux.

In cooperation with a project proposed for funding from NSF's ARCSS LAII program, measurements of $\mathrm{CO}_{2}$ and other trace gas flux at three spatial scales (plot, landscape, and mesoscale) using chamber, tower-based eddy correlation techniques and aircraft-based eddy correlation techniques will be made. The information obtained from each of these techniques will be analyzed and compared, especially in light of defining the most efficient approaches for estimating large spatial scale $\mathrm{CO}_{2}$ flux in the arctic. Remotely-sensed spectral indices, GIS, process models, and phenomenological models will be used to develop a methodology for efficiently estimating ecosystem $\mathrm{CO}_{2}$ flux over meso- and global scales. Initial testing of the applicability of these methods will be undertaken. Support from the Department of Energy is requested to for plot level measurements. Support from NSF is also requested for other aspects of scaling.

\section{DISCLAIMER}

This report was prepared as an account of work sponsored by an agency of the United States Government. Neither the United States Government nor any agency thereof, nor any of their employees, makes any warranty, express or implied, or assumes any legal liability or responsibility for the accuracy, completeness, or usefulness of any information, apparatus, product, or process disclosed, or represents that its use would not infringe privately owned rights. Reference herein to any specific commercial product, process, or service by trade name, trademark, manufacturer, or otherwise does not necessarily constitute or imply its endorsement, recommendation, or favoring by the United States Government or any agency thereof. The views and opinions of authors expressed herein do not necessarily state or reflect those of the United States Government or any agency thereof. 


\section{BRIEF OVERVIEW}

\section{Introduction}

The vast majority of the organic carbon found in northern ecosystems $(\approx 83 \%)$ is present in the soil as dead organic matter in the seasonally thawed upper soil layers (soil active layer), and in the uppermost layers of the permanently frozen ground (permafrost). Northern ecosystems (arctic, boreal forest, and northern bogs) contain up to $455 \mathrm{Gt}$ of $\mathrm{C}$ ( 1 gigaton $(\mathrm{Gt})=1$ petagram $=10^{15} \mathrm{~g}$ ) in the permafrost and soil active layer (Miller, 1981; Miller et al., 1983; Gorham, 1991; Oechel and Billings, 1992), an amount which may be as much as $60 \%$ of the approximately 750 $\mathrm{Gt} \mathrm{C}$ currently in the atmosphere as $\mathrm{CO}_{2}$. Arctic tundra ecosystems alone contain about $60 \mathrm{Gt} \mathrm{C}$ as living and dead organic matter, $90 \%$ of which is present belowground in the soil active layer and upper permafrost layers as dead organic matter.

Net carbon accumulation or loss is the balance between gross primary productivity (photosynthesis) and plant and soil respiration as well as generally small losses to herbivory. Net primary productivity often exceeds heterotrophic respiration in northern ecosystems (Gorham, 1991; Oechel and Billings, 1992). As a result, these ecosystems in the historic and recent geologic past have been net sinks for carbon with respect to the atmosphere of about 0.1 to $0.3 \mathrm{Gt} \mathrm{C}$ per year (Schell, 1983; Schell and Ziemann, 1983; Marion and Oechel unpubl. data; Miller et al., 1983; Post, 1990; Gorham, 1991; Oechel and Billings, 1992). Tussock tundra, which is the largest store of carbon in arctic terrestrial ecosystems $(29.1 \mathrm{Gt} \mathrm{C})$, was approximated to be accumulating carbon at the rate of $23 \mathrm{~g} \mathrm{C} \mathrm{m}^{-2} \mathrm{y}^{-1}$, or $0.02 \mathrm{Gt} \mathrm{C}$ per year worldwide, while wet tundra was estimated to contain $14.4 \mathrm{Gt} C$ worldwide and to be accumulating carbon at the rate of $27 \mathrm{~g} \mathrm{C} \mathrm{m}^{-2} \mathrm{y}^{-1}$, or $0.03 \mathrm{Gt} \mathrm{C}$ per year worldwide (Miller et al., 1983; Oechel and Billings, 1992). Substantially higher rates of carbon uptake $\left(40-120 \mathrm{~g} \mathrm{~m}^{-2} \mathrm{y}^{-1}\right)$ were estimated from cuvette measurements of photosynthesis and respiration, and from aerodynamic measurements of ecosystem $\mathrm{CO}_{2}$ flux made during the U.S. IBP in Alaska (Chapin et al., 1980; Coyne and Kelley, 1975). Low and tall shrub tundra have been calculated to accumulate approximately 10 and $29 \mathrm{~g} \mathrm{C}$ $\mathrm{m}^{-2} \mathrm{y}^{-1}$, respectively, and together account for an annual storage of $0.02 \mathrm{Gt} C$ per year.

Recent measurements of $\mathrm{CO}_{2}$ flux in arctic ecosystems (see below) indicate that tussock and wet tundra are now sources of $\mathrm{CO}_{2}$ to the atmosphere, possibly as a result of a recent change in climatic patterns. This may be the first significant observation of a major variation in ecosystem function from greenhouse warming and associated global change. However, there are uncertanties in extrapolating these plot level observations to regional and global scales.

Low temperatures, reduced rates of actual evapotranspiration, and impeded drainage (often due to the impervious layer created by permafrost) frequently result in cold, saturated soils near the surface, despite low rates of precipitation. These conditions result in decreased rates of soil decomposition, especially at depth in the soil (Gorham, 1991; Clymo, 1984). As soil organic matter accumulates, permafrost migrates upward incorporating and freezing new organic material. The decomposition rate of the organic matter in the permafrost is near zero, removing carbon from biospheric circulation for thousands of years or until the permafrost melts. Predicting future response of arctic ecosystems to elevated atmospheric $\mathrm{CO}_{2}$ and associated climate change is difficult. The net effect will depend on the relative response of photosynthesis to elevated $\mathrm{CO}_{2}$ and other environmental changes in relation to alterations in plant respiration rates and soil decomposition.

Under future conditions of elevated $\mathrm{CO}_{2}$ and global climate change, northern ecosystems could become a sink for carbon, providing a negative feedback on atmospheric $\mathrm{CO}_{2}$. It is likely, 
however, that northern ecosystems will be a source of $\mathrm{CO}_{2}$ and will have a positive feedback on the global climate (Billings, et al., 1982; Post, 1990; Oechel and Billings, 1992).

Climate change could result in higher temperatures, and altered precipitation possibly could increase the depth of the soil active layer and water table, resulting in warmer-soil temperatures and greater soil aeration. These factors could increase soil decomposition rates (Silvola, 1986; Gorham, 1991; Billings et al., 1982, 1983; Billings and Peterson, 1992). If soil decomposition increases more rapidly than net primary production, the system ceases to be a carbon sink and becomes a carbon source.

High latitude ecosystems are anticipated to undergo the most significant increases in surface temperature with a doubling of atmospheric $\mathrm{CO}_{2}$. Surface temperature increases of $4^{\circ} \mathrm{C}$ in summer and as much as $17^{\circ} \mathrm{C}$ in winter have been predicted for northern latitudes (Mitchell et al., 1990; Schlesinger and Mitchell, 1987). Although clouds and water vapor may feed back and limit the increase by as much as $50 \%$, there is a general consensus of significantly higher temperatures in the arctic. These projected increases in temperature are of importance in both the absolute and relative sense. The anticipated increases should be viewed with respect to current mean annual and mean summer (June through August) temperatures which, in the case of Barrow, Alaska, for example, are $-12^{\circ} \mathrm{C}$ and $+3^{\circ} \mathrm{C}$, respectively (Table 1, Fig. 1).

Global warming may already be occurring in arctic Alaska, where current temperatures appear warmer than in the historic or recent geologic past. Thermal profiles in the permafrost indicate a temperature rise across the north slope of Alaska of $2-4^{\circ} \mathrm{C}$ within the last century, and most likely within the last few decades (Lachenbruch and Marshall, 1986). Weather records indicate a distinct warming trend in much of the Canadian arctic and boreal forest (Hengeveld, 1991). Analysis of summer temperatures at Barrow $\left(71^{\circ} 18^{\prime} \mathrm{N}, 156^{\circ} 47^{\prime} \mathrm{W}\right)$ for the last 70 years (1921-1990) and Prudhoe Bay, Alaska for the last 20 years (1969-1990) shows a trend of increasing temperatures culminating in the warmest summer temperatures on record (Fig. 1). While it is impossible to definitively ascribe these recent temperature increases to greenhouse warming of the atmosphere, it is clear that current arctic temperatures are elevated over those of the historic and recent geologic past. The temperature increases are not inconsistent with global climate model predictions for greenhouse warming, given the $25 \%$ rise in atmospheric $\mathrm{CO}_{2}$ and higher atmospheric methane and other trace gas concentrations which have occurred since the initiation of the Industrial Revolution. Summer increases of $2-4^{\circ} \mathrm{C}$ would result in well above mean summer temperatures experienced by these ecosystems in the historic and recent geologic past, and would have profound impacts on ecosystem structure and function.

Our past DOE research has documented short-term changes in the photosynthetic response of arctic plants grown under controlled conditions on the time scale of minutes to months (Oberbauer et al., 1986). Plants grown at a $\mathrm{CO}_{2}$ concentration of $350 \mathrm{ppm}$ but measured at 675 ppm $\mathrm{CO}_{2}$ showed a $\mathrm{CO}_{2}$ enhancement of photosynthesis. However, after two months, plants grown at $675 \mathrm{ppm} \mathrm{CO} 2$ concentration, with photosynthesis measured at the same high growth $\mathrm{CO}_{2}$ concentration, exhibited similar rates to those grown and measured at $350 \mathrm{ppm} \mathrm{CO}$. A prolonged enhancement of photosynthesis by elevated $\mathrm{CO}_{2}$ generally requires that nutrients are abundant (Oechel and Strain, 1985), temperatures are warm (Kimball et al., 1986), or water is limited (Oechel and Strain, 1985). Biomass attributes of the plants in the growth chamber study were strongly enhanced by nutrients, but there was no interaction between nutrition and $\mathrm{CO}_{2}$ concentration (Oberbauer et al., 1986). Increased nutrients had little or no effect on maintaining a $\mathrm{CO}_{2}$ enhancement of photosynthesis. This suggests that the physiological limitations to use additional $\mathrm{CO}_{2}$ may be inherent to the arctic species studied.

The results of the growth chamber studies are similar to those of plants treated and measured in the field (Tissue and Oechel, 1987) using a similar time scale. In the field, Eriophorum vaginatum showed a nearly perfect homeostatic adjustment to higher $\mathrm{CO}_{2}$ levels 
*Summer months from June-August. †This study, missing 22 days of data. \$Toolik River, MS-117, D. Kane, University of Alaska (personal communication). §This study. /Toolik River, MS-117, R.J. McClure, USDA. INational Climatic Data Center, Asheville, N.C. computed from the mean minimum and mean maximum recorded temperatures. \#Toolik River, MS-117, R.H. Haugen, Cold Regions Research and Engineering Laboratory, Hanover, New Hampshire. ${ }^{* *}$ N.D. Not Determined.

Table 1. Characteristics of research sites and measured $\mathrm{CO}_{2}$ fluxes. Negative values indicate ecosystem sequestering from the atmosphere; positive values indicated $\mathrm{CO}_{2}$ loss to the atmosphere. Daily $\mathrm{CO}_{2}$ flux measurements are Calculated from diurnal measurements, and averaged for the period of biological activity.

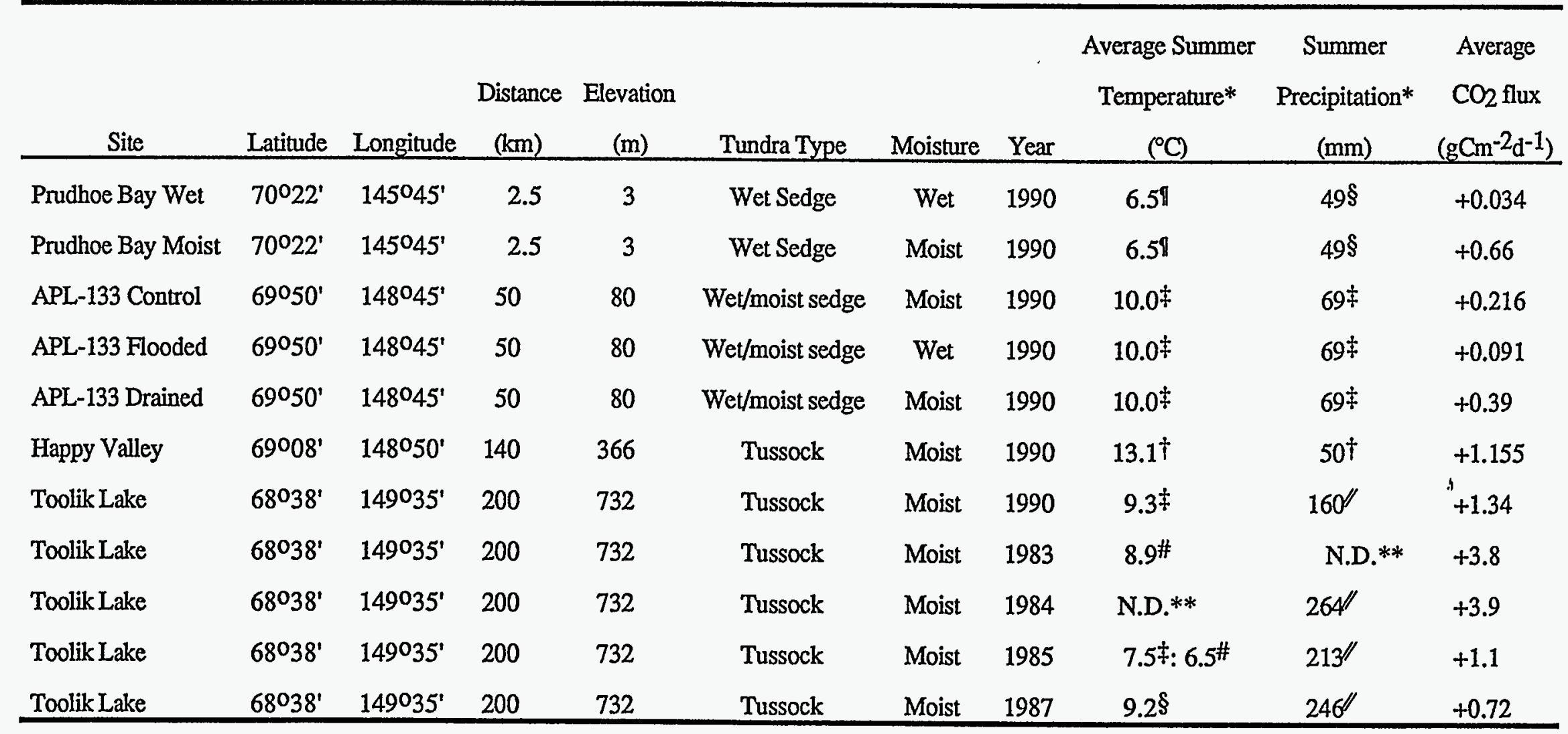


(Oechel et al., 1992). This pattern may reflect the carbohydrate sufficiency in $E$. vaginatum and many other arctic plants (Shaver and Chapin, 1980; Chapin et al., 1986; Tissue and Oechel, 1987). Without adequate sinks, accumulated carbohydrates may feed back to reduce the amount of RuBP with a concomitant reduction in photosynthesis (Tissue and Oechel, 1987). An increase in

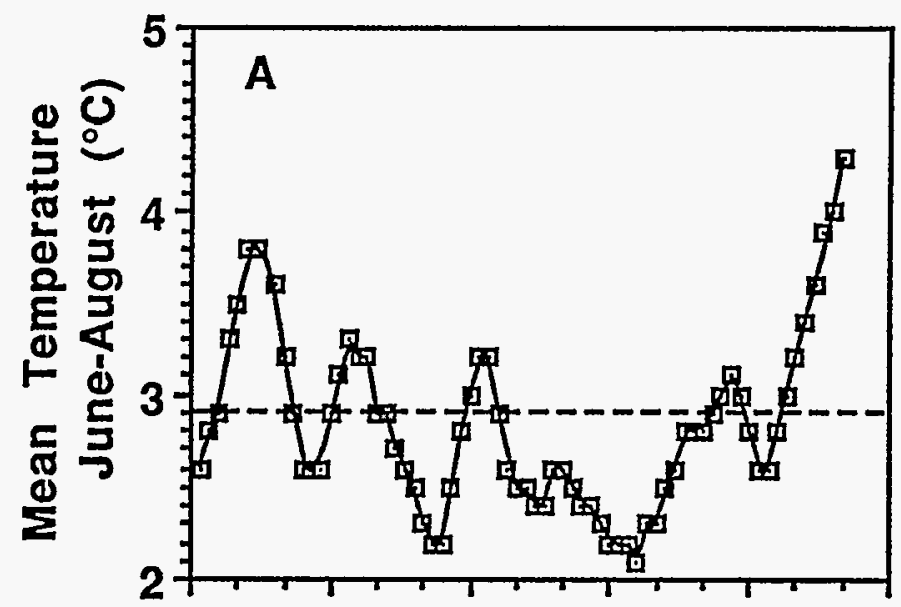

192019351950196519801995

Year

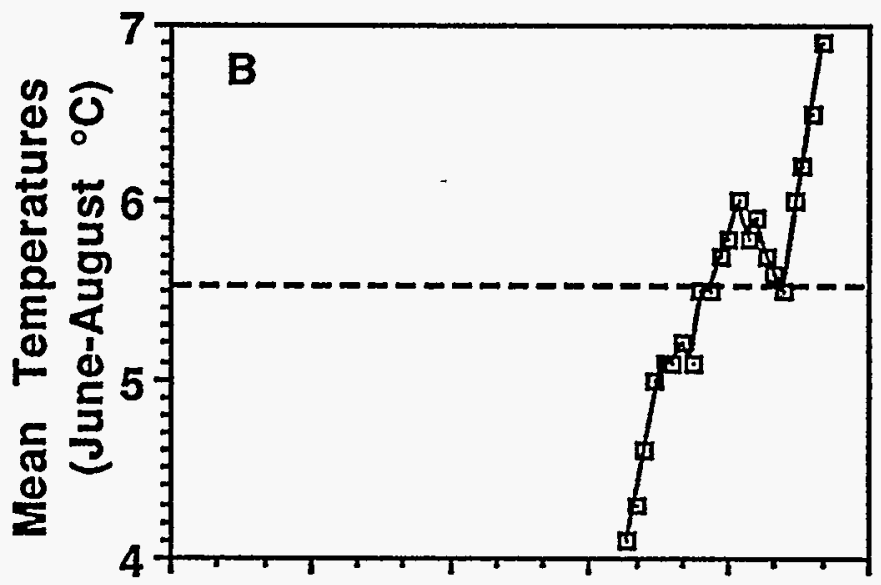

192019351950196519801995

Year

Fig. 1. Mean annual summer (June through August) temperatures from 1920 to 1990 at Barrow, Alaska (A) and from 1969 to 1990 at Prudhoe Bay, Alaska (B). Represented are five-year sliding mean values from the U.S. Weather Service for Barrow, Alaska and from ARCO for the ARCO airport tower at Prudhoe Bay, Alaska (except for the first and last values in each case which represent the means of the three available years, and the next to the first and last values which represent the means of the four years available). 
temperature and $\mathrm{CO}_{2}$ did not stimulate the field plants with respect to leaf area (Tissue and Oechel, 1987).

However, a nearly threefold increase in tiller production was observed in the plants grown under elevated $\mathrm{CO}_{2}$ vs. ambient. This could have a significant effect on popalation dynamics, competition, and finally on composition, biomass, and production (Tissue and Oechel, 1987).

Interestingly, when the water table was held constant, elevated temperature resulted in an increase in net ecosystem carbon sequestering in the field at elevated atmospheric $\mathrm{CO}_{2}$. In microcosms in the laboratory under ambient $\mathrm{CO}_{2}$, elevated temperature caused a reduction in net carbon sequestering. This reduction was larger where the water table was lower (Oechel and Billings, 1992).

Information on the controls of photosynthesis of individual plants in the laboratory and field, can to a degree, be used to predict whole-ecosystem response to elevated $\mathrm{CO}_{2}$ and climate change. However, the time period for adjustment of whole-ecosystem flux to elevated $\mathrm{CO}_{2}$ was found to be on the order of one to three years (Oechel and Riechers, 1986; Grulke et al., 1990) and even longer-term processes may be important in controlling carbon flux with respect to global

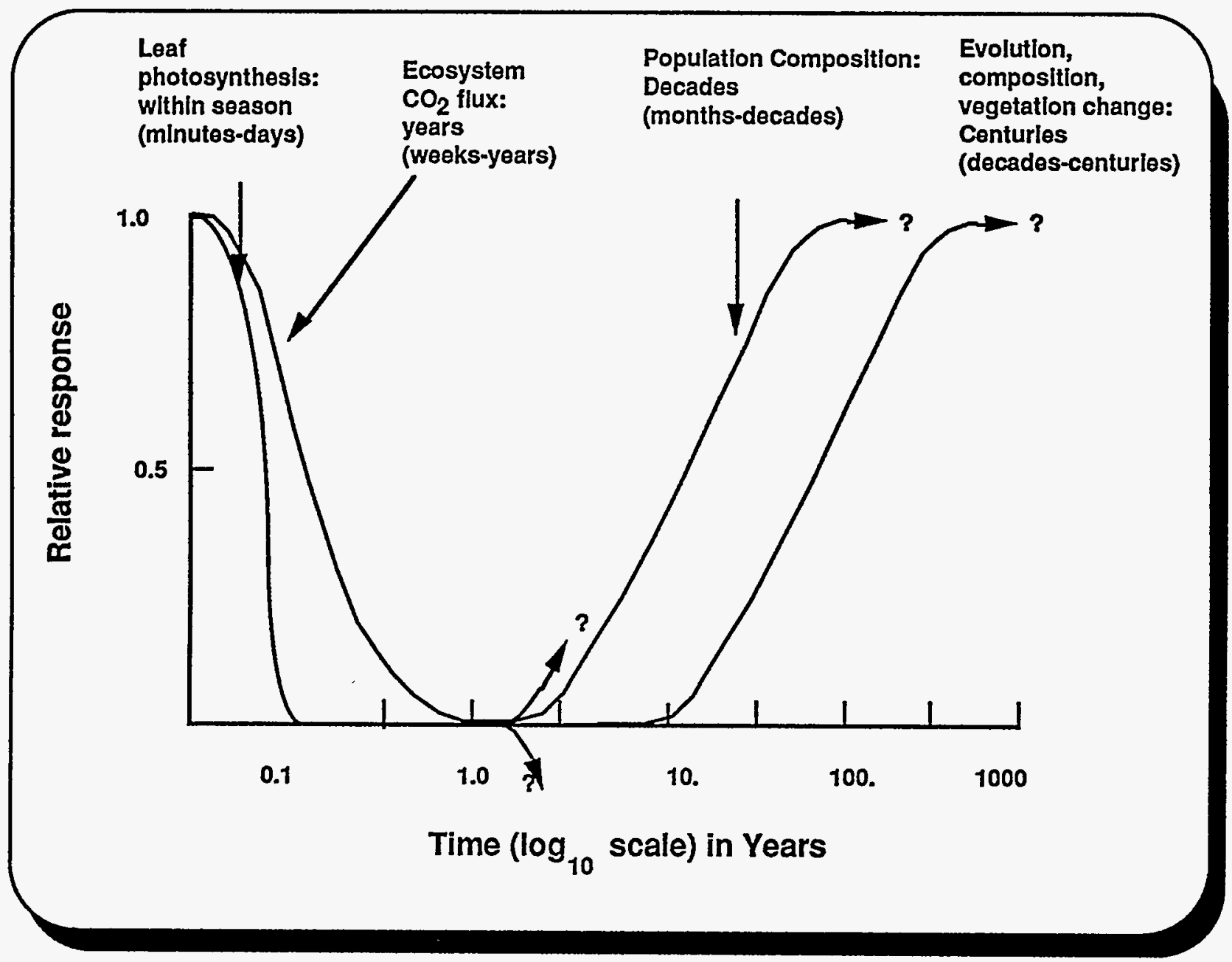

Fig. 2. Hypothesized time constants for the effects of increasing atmospheric $\mathrm{CO}_{2}$ on key processes affecting ecosystem net carbon accumulation (Oechel and Billings, 1992). 


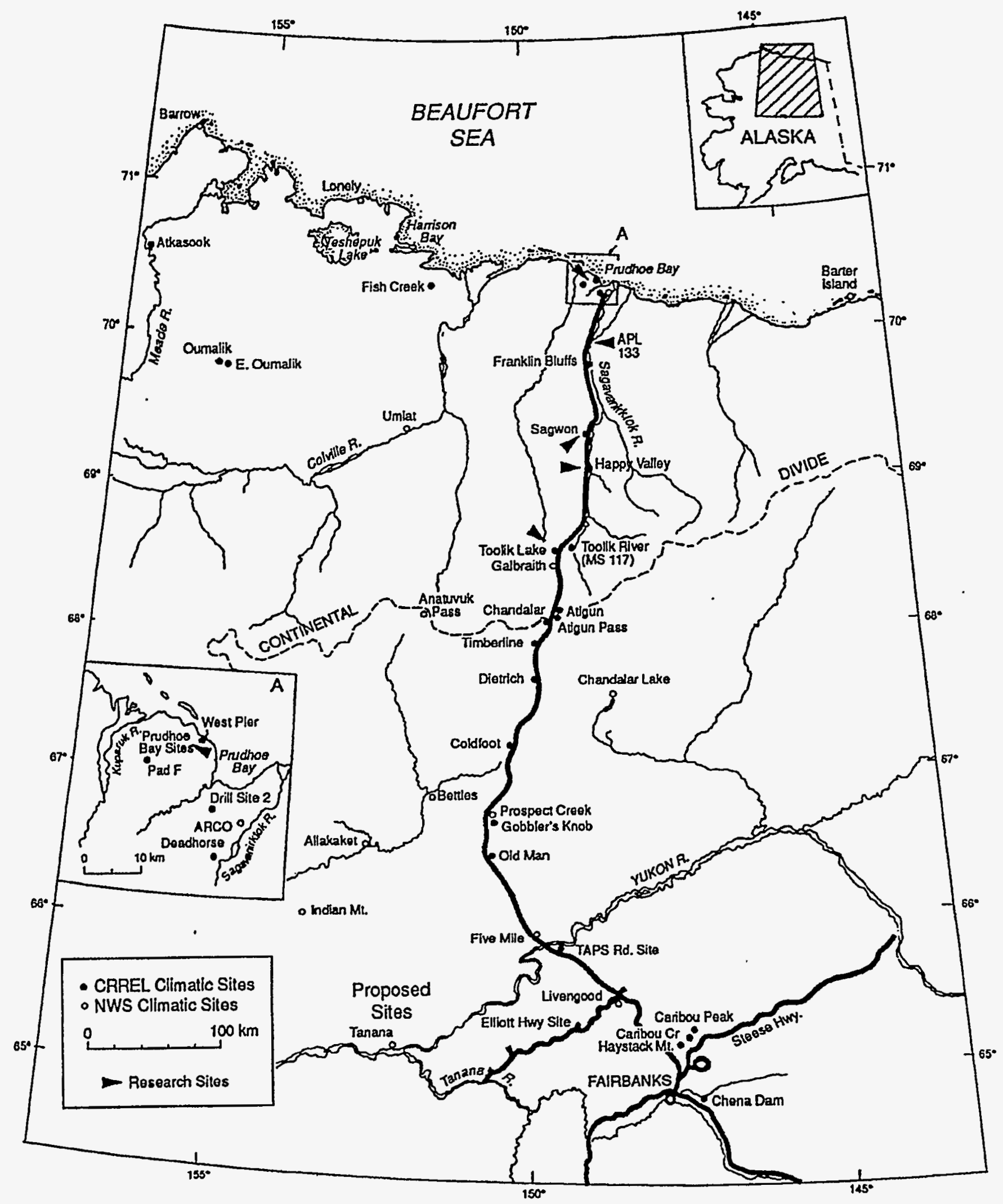

Fig. 3 Research sites for plot chamber measurements (triangles), tower eddy correlation landscape measurements (Prudhoe Bay and Happy Valley), and proposed flight lines for aircraft-based eddy correlation measurements (dashed lines). 
change. These longer-term processes include changes in population dynamics, competition, ecosystem composition, ecotypic differentiation, vegetation migration, and natural selection (Fig. 2, Oechel et al., 1992).

We have measured whole-ecosystem $\mathrm{CO}_{2}$ flux over six seasons $(1983-1985,1987,1990$, and 1991) at Toolik Lake and along a latitudinal transect in 1990 and 1991, from the Arctic Ocean at Prudhoe Bay to Toolik Lake, Alaska (Fig. 3). We report current rates of $\mathrm{CO}_{2}$ flux from tussock tundra and wet tundra ecosystems and consider possible effects of global change on future carbon balance.

\section{Current Rates of Carbon Flux on the North Slope of Alaska}

Despite active gross primary productivity, net ecosystem productivity was negative (positive carbon flux to the atmosphere) throughout the day at most sampling locations. For example, at Happy Valley on 18 June, 1991, gross ecosystem productivity was positive (negative flux from the atmosphere to the ecosystem) at all times throughout the 24-hour period of light (Fig. 4). However, ecosystem respiration was even stronger, and net ecosystem $\mathrm{CO}_{2}$ flux resulted in net accumulation for only three of the sampling times measured over a 24-hour period. Overall, there was a strong loss to the atmosphere on this date at this location (positive flux).

Some locations have a positive carbon balance (negative flux) on various days during the season. The moist site at Prudhoe Bay, which is losing carbon to the atmosphere on an annual basis, had a positive carbon balance (negative flux) on certain days near peak season. For example, on 30 June, 1991 (Fig. 5), gross productivity exceeded respiration for much of the day, resulting in a positive carbon balance (negative flux) for that day. This reflects the wetter nature of

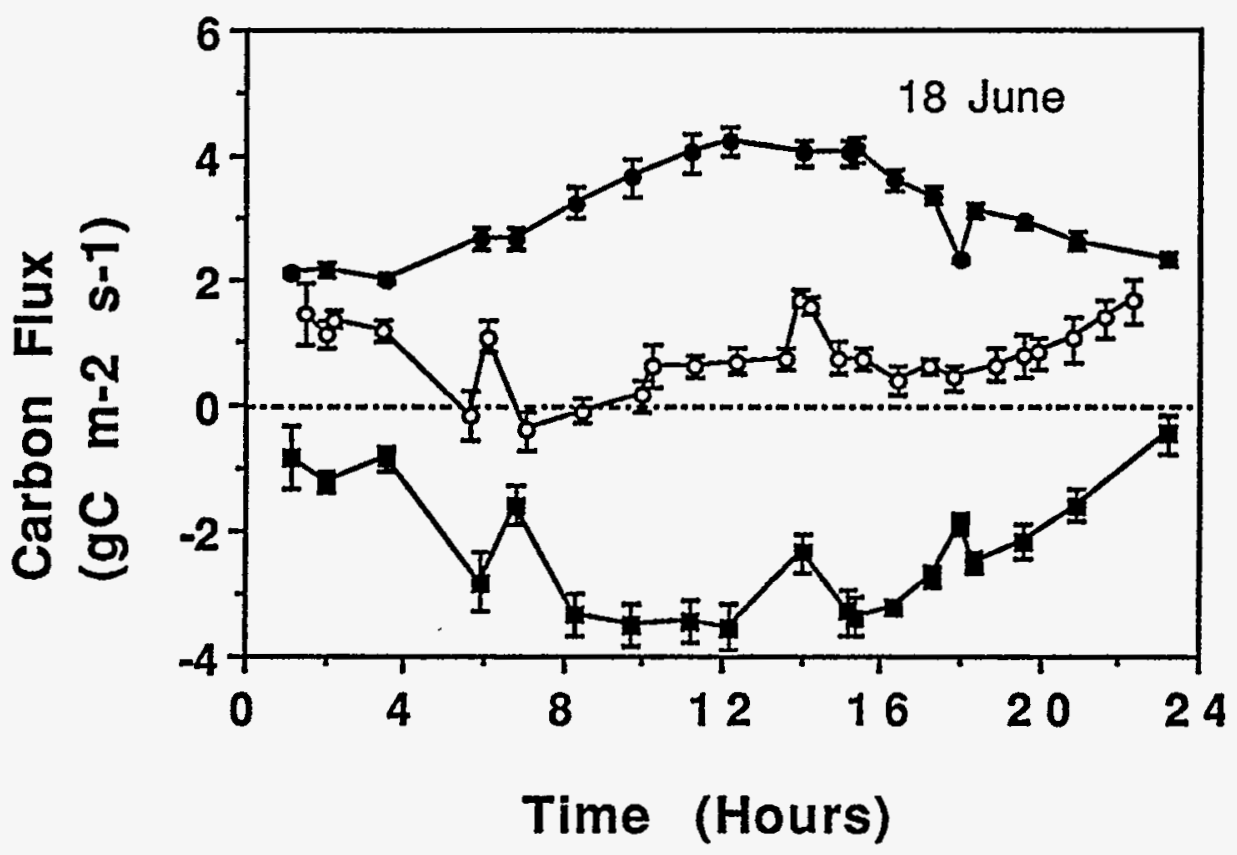

Fig. 4. Diurnal $\mathrm{CO}_{2}$ flux at the Happy Valley tussock tundra site on 18 June, 1991. Data are means $\pm 1 \mathrm{se}, \mathrm{n}=4$. Positive values indicate flux to the atmosphere, while negative values indicate flux from the atmosphere to the tundra ecosystem. Closed circles represent ecosystem respiration; closed squares represent gross primary productivity; open circles represent net ecosystem $\mathrm{CO}_{2}$ flux. 


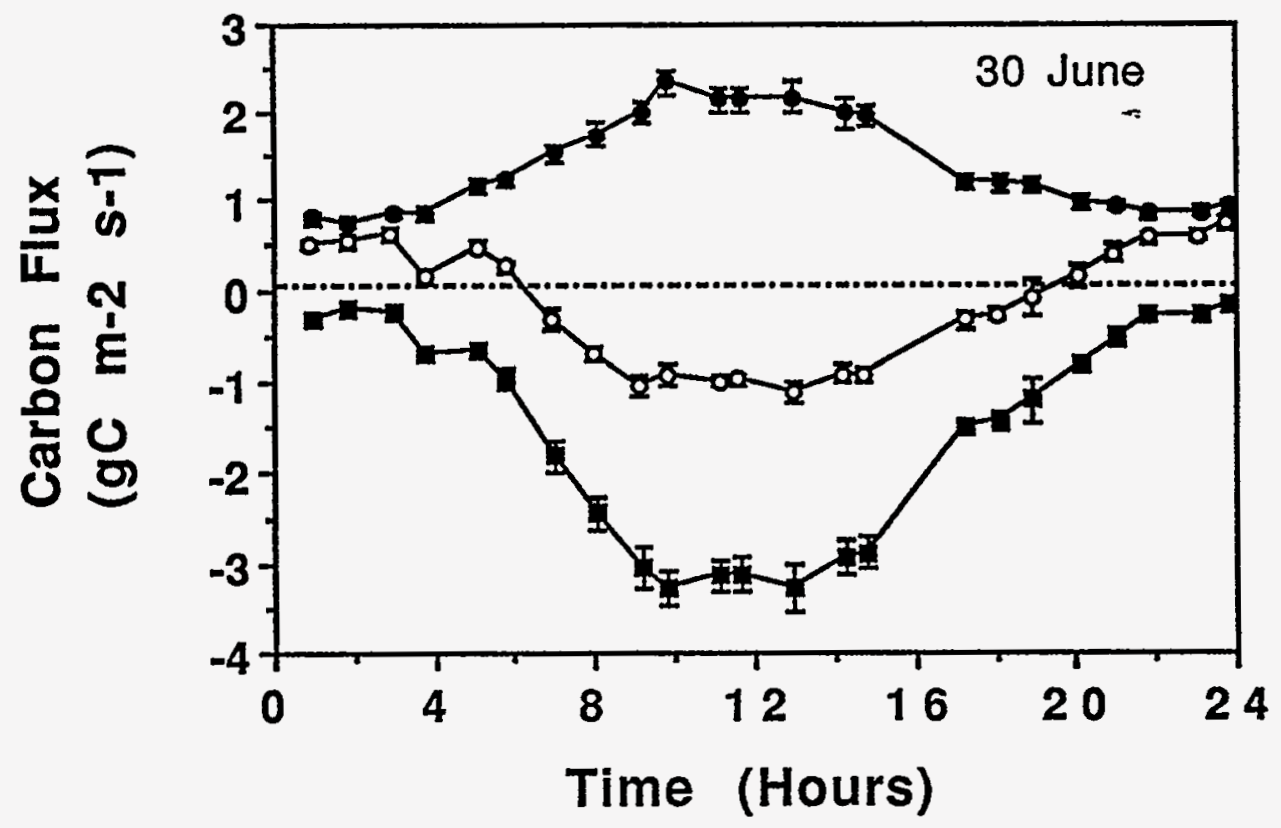

Fig. 5. Diurnal $\mathrm{CO}_{2}$ flux at the Prudhoe Bay moist wet coastal tundra site on $30 \mathrm{June}, 1991$. Data are means $\pm 1 \mathrm{se}, \mathrm{n}=4$. Positive values indicate flux to the atmosphere, while negative values indicate flux out of the atmosphere. Closed circles represent ecosystem respiration; closed squares represent gross primary productivity; open squares represent net ecosystem $\mathrm{CO}_{2}$ flux.

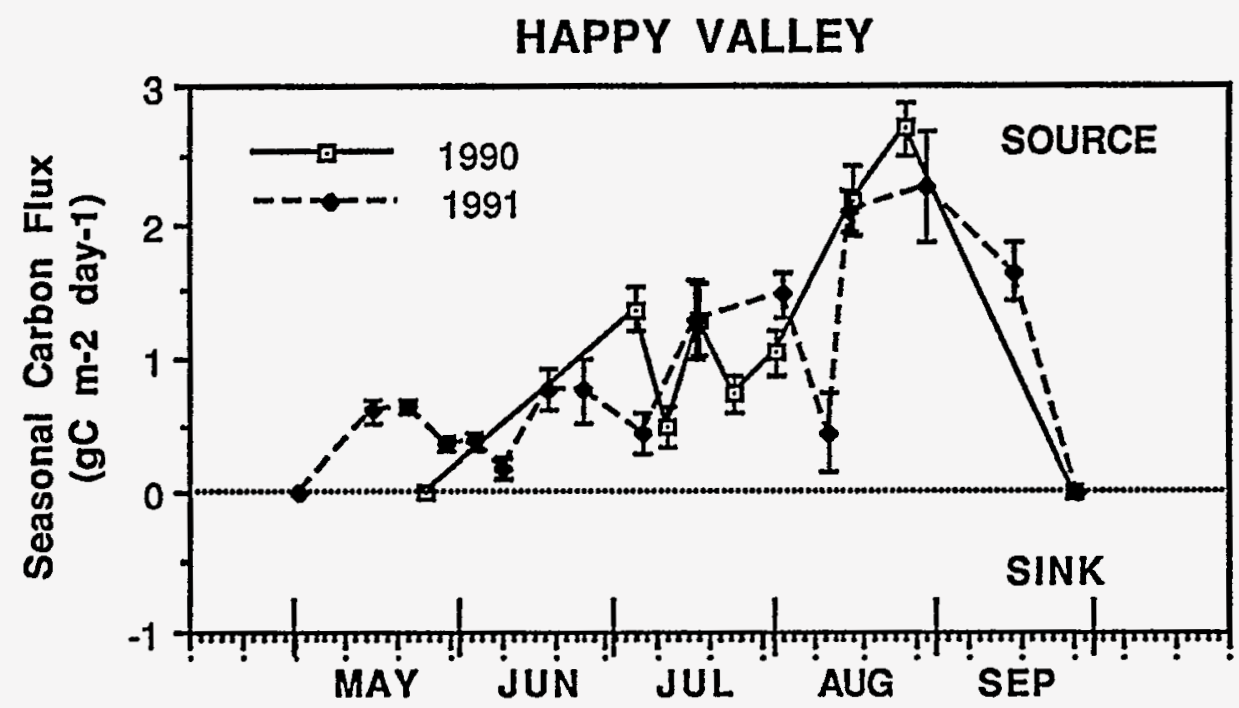

Fig. 6. Seasonal net ecosystem carbon flux at the Happy Valley tussock tundra site during the 1990 and 1991 growing seasons. Values presented are means \pm 1 se, $n=6$ for 1990 and $n=4$ for 1991 . 
the coastal tundra in the region. On no days in 1990 or 1991 was carbon balance positive (negative flux) at Happy Valley (Fig. 6) or Toolik Lake.

The seasonal patterns of net $\mathrm{CO}_{2}$ fluxes were quite similar in 1990 and 1991. At Happy Valley, for example, carbon loss occurred from the period of snow melt to soil freeze-up in both years measured (Fig. 6). The variations that do occur are related to differences in weather conditions during and surrounding the measurement period.

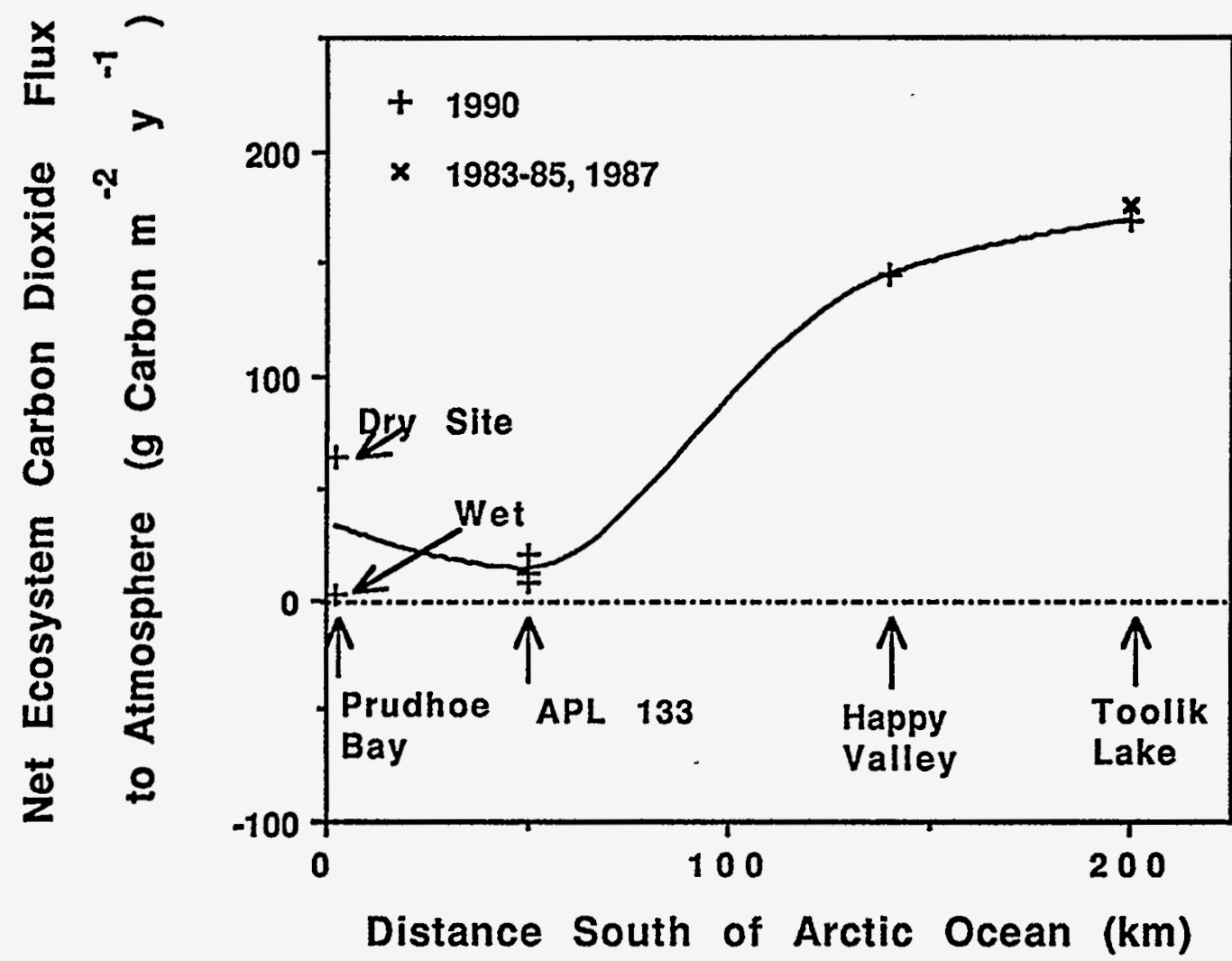

Fig. 7. Seasonal carbon dioxide flux (as carbon) along a latitudinal gradient from Prudhoe Bay to Toolik Lake, Alaska in 1990 ("+" symbols), and for four additional years of measurement at Toolik Lake (1983-1985, 1987, "x" symbol). The line presented represents an interpolation of values for 1990. Mean flux for 1983-1985, and 1987 is 175 $\pm 62 \mathrm{~g} \mathrm{C} \mathrm{m}^{-2} \mathrm{y}^{-1}$ (mean \pm 1 s.e.). Site differences in soil moisture are noted at Prudhoe Bay. The three values at APL-133 represent the three areas of varying moisture availability (drained, control and impounded) studied which resulted in higher, medium, and lower $\mathrm{CO}_{2}$ efflux from the tundra to the atmosphere, respectively (Table 1).

Generally carbon loss to the atmosphere during the 1990 season increased from north to south (Fig. 7), and in the drier areas within a site (Table 1). The location closest to the coast, Prudhoe Bay wet, was the wettest site measured and contained the highest water table (Table 1). The southern sites, Toolik Lake and Happy Valley, were better drained, had greater thaw depths, and lower water tables. The average rate of annual $\mathrm{CO}_{2}$ loss for the tussock tundra sites (Toolik Lake and Happy Valley) in 1990 was $156 \mathrm{~g} \mathrm{C} \mathrm{m}^{-2} \mathrm{y}^{-1}$, while carbon loss for the wet coastal tundra 
sites (Prudhoe Bay and APL-133-3) was approximately $34 \mathrm{~g} \mathrm{C} \mathrm{m}^{-2} \mathrm{y}^{-1}$ (Table 1). The results for the tussock tundra ecosystems during the 1990 sampling season agree with findings reported during the initial measurements made between 1983 and 1987 (Table 1). These data indicate a change in carbon balance of the tundra, and an ecosystem response to the recent trend in climate warming reported for the north slope of Alaska. If this is a general trend which is exacerbated by future global warming, huge amounts of carbon could be injected into the atmosphere as $\mathrm{CO}_{2}$ in the decades or centuries prior to stabilization of the $\mathrm{CO}_{2}$ flux or reversal of the trend (e.g. due to changes in the plant communities present).

The APL-133 site exhibited the lowest rates of carbon loss to the atmosphere. This may reflect its transitional status from tussock tundra to the south and wet sedge tundra to the north. As such, it was on the dry extreme of wet sedge tundra but on the wet extreme of tussock tundra sites measured. The species composition at APL-133 is primarily Carex aquatilis and Eriophorum angustifolium. The site had little slope, and as a result contained a high water table and was fairly moist. A dry site at APL-133 shows components of tussock tundra including Salix reticulata, Vaccinium vitis-idaea, and Arctostaphylos rubra but not the tussock-forming sedge, $E$. vaginatum. This site exhibited the lowest loss of carbon to the atmosphere of any of the upland tundra sites. A gravel road built in the area in 1974 modified the pattern of drainage, and provided areas of exceptional moisture or drought (Table 1). The areas receiving additional moisture showed decreased rates of carbon loss compared to areas where the inflow of water was reduced by the pad and road (Fig. 7, Table 1).

We believe that the change from carbon accumulation to carbon loss in these arctic ecosystems is not directly due to a rise in temperature, but instead results from indirect effects of increased temperature which causes enhanced drainage and soil aeration, and a decrease in the water table (Oechel and Billings, 1992; Post, 1990). Decomposition of the soil organic layer in northern peat lands is controlled to a much greater extent by drainage, and consequently soil aeration, than by temperature (Billings et al., 1982, 1984; Gorham, 1991). Warmer periods in the past, however, resulted in peat accumulation in the Canadian subarctic, where there is currently no evidence of carbon accumulation (Gorham, 1991).

Given the general pattern of warming reported for the north slope of Alaska (Lachenbruch and Marshall, 1986; Lachenbruch et al., 1988) and for areas of the Canadian arctic (Hengeveld, 1991), the patterns observed along this latitudinal transect in Alaska may be fairly general. If the average rate of loss in tussock tundra of $156 \mathrm{~g} \mathrm{~m}^{-2} \mathrm{y}^{-1}$ along the transect measured in 1990 is typical for circumpolar tussock tundra, the loss of carbon to the atmosphere in 1990 from the 0.90 $10^{6} \mathrm{~km}^{2}$ of tussock tundra worldwide (Miller et al., 1983) would be $0.14 \mathrm{Gt} \mathrm{C}$ per year. Similarly, if the $34 \mathrm{~g} \mathrm{C} \mathrm{m}^{-2} \mathrm{y}^{-1}$ of carbon dioxide evolution from wet tundra is applied to the 1.00 $10^{6} \mathrm{~km}^{2}$ of wet coastal tundra, another $0.03 \mathrm{Gt} \mathrm{C}$ per year is calculated to be lost annually to the atmosphere. There may be decreases in uptake rates or absolute losses in carbon from other tundra types. This may be the first major change in ecosystem carbon flux detected from recent climatic warming and concomitant environmental change.

According to the above calculations, tussock tundra and wet coastal tundra in Alaska are losing carbon to the atmosphere at a rate equivalent to $0.17 \mathrm{Gt} C$ per year for the world's circumpolar tundra. Another $0.02 \mathrm{Gt} \mathrm{C}$ per year lost from arctic tundra lakes and rivers should be added to this loss (Kling, Kipphut, and Miller, 1991), resulting in a total annual loss of $0.19 \mathrm{Gt}$ C from these circumpolar arctic areas. This combined efflux can be compared to the 0.2 to $0.7 \mathrm{Gt} C$ calculated to be lost to the atmosphere from high latitude (arctic and/or northern boreal forest) ecosystems by Tans et al. (1990) in their modelling scenarios 6, 7, and 8. Given the large belowground stores of carbon in arctic, boreal forest, and high latitude bogs, these high latitude ecosystems could pose a significant positive feedback on increasing atmospheric $\mathrm{CO}_{2}$ and concomitant global warming. 


\section{Research Needs}

\section{Effects of long-term exposure to elevated atmospheric $\mathrm{CO}_{2}$}

Higher atmospheric $\mathrm{CO}_{2}$ has the potential to increase plant growth in various ways including greater photosynthesis, higher water-use efficiency, depression of respiration, delayed leaf senescence, and relief of nutrient stress via mechanisms including increases in nutrient-use efficiency, nitrogen fixation, and nutrient uptake (Oechel and Strain, 1985; Bazzaz, 1990; Mooney et al., 1991). There is, however, great uncertainty about whether these responses will hold for prolonged periods in natural ecosystems as most of the research conducted has been of short duration on agricultural species under optimal conditions. Some scientists have argued that limitations of water, nutrients, and light will prevent most unmanaged ecosystems from exhibiting significant responses to elevated atmospheric $\mathrm{CO}_{2}$ (Kramer, 1981; Melillo et al., 1990).

It is likely that the response of ecosystems to elevated atmospheric $\mathrm{CO}_{2}$ will depend on both resource availability with respect to resource demand, and on the genetic constrains of the organisms affected. In the arctic, elevated levels of $\mathrm{CO}_{2}$ causes an initial stimulation of photosynthesis in the tussock tundra plant Eriophorum vaginatum, but complete homeostatic adjustment of photosynthesis occurs within three weeks of exposure to elevated atmospheric $\mathrm{CO}_{2}$ (Oechel and Tissue, 1987). Other species making up the system may respond faster, slower, or in a different fashion. In controlled growth chamber experiments, and with ample resource availability, the response to elevated $\mathrm{CO}_{2}$ was minimal. This suggests a genetic limitation to the ability to respond to elevated atmospheric $\mathrm{CO}_{2}$, even in the presence of ample nutrients and other resources (Oberbauer et al., 1986). Nevertheless, within three growing seasons, ecosystem flux adjusts so that net ecosystem $\mathrm{CO}_{2}$ fluxes are similar at elevated and current ambient atmospheric $\mathrm{CO}_{2}$ concentrations (Oechel et al., 1992).

However, experimental manipulations of atmospheric $\mathrm{CO}_{2}$ in the arctic have been maintained for only three consecutive growing seasons. Changes in other factors such as tillering rates, carbon allocation, sexual and asexual reproduction, and timing of senescence occur over periods of decades to centuries. Species composition may be affected with concomitant effects on ecosystem function including tundra carbon balance (Oechel et al., 1992). We know that plant species respond differentially to elevated atmospheric $\mathrm{CO}_{2}$ and climatic change, resulting in varying patterns of growth, survival, and competition (Oberbauer et al., 1986; Bazzaz, 1990). Changes in reproductive and population characteristics will affect community composition and, therefore, net ecosystem primary productivity and $\mathrm{CO}_{2}$ flux. Over longer time periods, ecotypic differentiation and selection may result in populations that respond more aggressively to elevated. $\mathrm{CO}_{2}$, thereby altering net ecosystem carbon balance. This may contribute to changing vegetation boundaries. Replacement of tundra by boreal forest will also affect ecosystem carbon flux and aboveground carbon storage.

To determine the longer-term responses to elevated $\mathrm{CO}_{2}$, it is desirable to study arctic ecosystems which have been exposed to elevated atmospheric $\mathrm{CO}_{2}$ for decades to centuries, or longer. This can be accomplished where cold $\mathrm{CO}_{2}$ springs elevate the atmospheric $\mathrm{CO}_{2}$ content. Several arctic areas are known to have such $\mathrm{CO}_{2}$ springs. One particularly good area is Iceland which not only has an abundance of uncontaminated $\mathrm{CO}_{2}$ springs, but also has good infrastructural support (Cook, Oechel, and Sveinbjornsson, unpub. data). Information regarding the effects of long-term $\mathrm{CO}_{2}$ fertilization on species composition, biomass, carbon storage, carbon flux, and ecotypic differentiation is needed. Natural sources of $\mathrm{CO}_{2}$ gradients found around mineral springs provide a mechanism for studying the long-term effects of elevated atmospheric $\mathrm{CO}_{2}$ on plant communities and ecosystems. What may occur in the next 10-100 years can perhaps 
be predicted from what has taken place in the vicinity of $\mathrm{CO}_{2}$ springs providing important insight into future changes at the soil, plant, and ecosystem level with regard to changing $\mathrm{CO}_{2}$.

\section{Circumpolar patterns of net ecosystem $\mathrm{CO}_{2}$ flux}

Our research indicates massive, recent, efflux of $\mathrm{CO}_{2}$ from arctic tundra to the atmosphere for the central north slope of Alaska. We believe, however, based on reported circumpolar climate patterns, that these patterns may be more general. If the pattern of decreasing carbon storage (and actual carbon loss) from arctic tundra holds for the circumpolar coastal and moist tussock tundra vegetation, the impacts on terrestrial carbon budget and global warming would be significant. Research is needed to determine the pattern of $\mathrm{CO}_{2}$ flux in other circumpolar tundra areas. Because of the large areal extent of arctic tundra in Russia, this is an area of obvious research need. Other areas requiring study include Scandinavia and Canada.

\section{In situ controls by temperature and moisture on net ecosystem $\mathrm{CO}_{2}$ flux}

The most likely effects of climate change in tundra ecosystems will be higher soil temperatures, resulting in an increase in thaw depth and a decrease in soil moisture status (Oechel and Billings, 1992; Post, 1990). These factors would lead to increased soil temperature and aeration, resulting in higher soil decomposition rates (Silvola, 1986; Gorham, 1991; Billings et al., 1982, 1983; Billings and Peterson, 1992). Due to uncertainties regarding the effects of climate change on local weather patterns, a scenario predicting higher soil temperatures and precipitation has also been suggested (Post, 1990). This may lead to lower soil aeration, resulting in reduced aerobic soil respiration and $\mathrm{CO}_{2}$ production, but higher rates of anaerobic respiration and $\mathrm{CH}_{4}$ production.

In order to understand and predict the effects of global change on net ecosystem carbon flux, it is necessary to understand the effects of modification of various environmental factors including temperature, soil moisture, and elevated atmospheric $\mathrm{CO}_{2}$ on processes which affect net ecosystem carbon flux. Some studies are available, but manipulations to understand the effects of individual environmental factors of temperature and moisture on net ecosystem $\mathrm{CO}_{2}$ flux have primarily been carried out in the laboratory (Oechel and Billings, 1992). The net effect of increasing temperature and decreasing soil moisture on the components of ecosystem carbon flux are unknown. These need to be studied in field and laboratory conditions to establish predictive understanding of the net effect of changing combinations of environmental factors on ecosystem carbon balance.

\section{Scaling of $\mathrm{CO}_{2}$ flux from plot to landscape and regional scales}

Unfortunately, to extrapolate chamber (plot) level measurements to landscape and regional levels requires more than sampling and multiplying by the respective surface areas at the scales of interest. Part of this is due to difficulties of sampling the inherent heterogeneities at the scales of interest. Landscape and regional scales involve many different vegetation, environment, slope, and geological situations (surface terrain units). It is impossible to adequately sample all of these surface terrain units at the plot level with sufficient replication through the day and season to allow a simple summing to produce the landscape and regional net ecosystem $\mathrm{CO}_{2}$ fluxes.

Quantifying carbon flux over large regions will require application of new approaches and methodologies to the arctic. Plot measurements using chambers are currently the most accurate method of assessing carbon flux over small (square meter) scales. However, while accurate at the plot level, substantial errors may accumulate in scaling and in extrapolating in space and time. Also, determining reliable $\mathrm{CO}_{2}$ flux estimates from plot flux measurements is very time consuming and manpower intensive. Tower-eddy correlation measurements provide a larger scale of $\mathrm{CO}_{2}$ flux interaction, with the footprint or area of measurement over the scale of a few kilometers. Aircraft 
measurements provide the most extensive capability of $\mathrm{CO}_{2}$ flux measurement (Desjardins et al., $1989,1990 \mathrm{a}, \mathrm{b})$. By moving the tower, and/or selecting measurements to coincide with differing wind movement, it is possible to determine the $\mathrm{CO}_{2}$ flux from various vegetation types.

Aircraft-eddy correlation measurements appear to be the best direct approach to assess the actual carbon flux over large landscape units. However, since airborne measurements do not directly measure $\mathrm{CO}_{2}$ flux at the scale normally measured and manipulated on the ground, it is necessary to develop appropriate scaling routines to understand the contributions of these units to the airborne measurement. Also, it may not be practical to obtain extensive diurnal and seasonal measurements over large areas by aircraft. By developing appropriate models and scaling routines, diurnal and seasonal fluxes can be calculated for large regions from targeted samplings using chamber and tower-eddy correlation measurements.

\section{Objectives}

The overall objective of this proposed research is "to document current patterns of $\mathrm{CO}_{2}$ flux in selected locations of the circumpolar arctic and to develop the information necessary to predict how these fluxes may be affected by elevated atmospheric $\mathrm{CO}_{2}$ and climate change". The research proposed for the next three years falls into four principal areas. These are:

A) Long-term response of arctic plants and ecosystems to elevated atmospheric $\mathrm{CO}_{2}$.

B) Circumpolar patterns of net ecosystem $\mathrm{CO}_{2}$ flux.

C) In situ controls by temperature and moisture on net ecosystem $\mathrm{CO}_{2}$ flux.

D) Scaling of $\mathrm{CO}_{2}$ flux from plot, to landscape, to regional scales (in conjunction with research proposed for NSF support).

All areas build on our past research and contribute to answering the overall objectives above. These objectives build on particular windows of opportunity (research in Russia and Iceland) and/or cooperation with other agencies (e.g. with NSF on scaling and site manipulations).

\section{Specific Objectives:}

1. Determine the effects of short- and long-term (i.e. $\geq$ centuries) exposure to elevated atmospheric $\mathrm{CO}_{2}$ on photosynthesis and respiration of the dominant vascular plant species (Eriophorum angustifolium) and certain other plant species. Determine the effect of exposure to elevated atmospheric $\mathrm{CO}_{2}$ on net ecosystem carbon flux, biomass, and species composition.

Explanation. Ecophysiological measurements of photosynthesis and respiration will be made on Eriophorum angustifolium. Also, reciprocal transplant and controlledenvironment growth chamber studies for the evaluation of genetic adaptation will be conducted. Net ecosystem $\mathrm{CO}_{2}$ flux and other ecosystem attributes will be compared between systems with and without long-term exposure to elevated atmospheric $\mathrm{CO}_{2}$.

2. Determine the seasonal carbon balance along a latitudinal transect on the Taymyr Peninsula and in western Iceland.

Explanation. These data will be used to evaluate the generality of results from Alaska to areas of the Russian and Icelandic arctic. Much of the arctic falls outside Alaska. If recent 
changes in climate at high latitudes are reflected in carbon flux of the circumpolar arctic tundra, the feedbacks on atmospheric rise in $\mathrm{CO}_{2}$ could be significant.

3. Determine the influence of soil environmental variables on $\mathrm{CO}_{2}$ flux within the dominant habitat types.

Explanation. These studies help us understand the controls on carbon flux in arctic tundra and the mechanisms involved. This information will allow us to predict the effect of anticipated scenarios of climate change on net ecosystem $\mathrm{CO}_{2}$ flux. In situ field and controlled-environmental studies will be used. Where possible, this research objective will utilize manipulations in the arctic established as part of the NSF's ITEX (International Tundra Experiment) contribution.

4. Determine the contribution of local vegetation terrain units (ecosystem and habitat types) to landscape and regional fluxes.

Explanation. This information will allow understanding of the contribution of differing vegetation-habitat types to the landscape and regional patterns of $\mathrm{CO}_{2}$ flux. In conjunction with research sponsored by NSF's ARCSS LAII, this research will allow a development of scaling from the plot to regional levels (Appendix III). Techniques and models developed in the course of this research will allow evaluation of the impacts of changing vegetation patterns and distribution on regional $\mathrm{CO}_{2}$ flux patterns with the atmosphere.

\section{HYPOTHESES}

The following hypotheses will be investigated over the course of this proposed research. The hypotheses are generally stated in their positive form for clarity.

\section{Hypothesis 1: Eriophorum angustifolium exhibits down regulation of photosynthesis (homeostatic adjustment or acclimation) following long-term exposure (decades to centuries) to elevated levels of atmospheric $\mathrm{CO}_{2}$.}

Explanation. Arctic plants are less limited by $\mathrm{CO}_{2}$ than by mineral nutrients or temperature. Increases in $\mathrm{CO}_{2}$ will therefore have no measurable effect after decades or centuries due to physiological adaptation to low temperatures and nutrient availability. This was found after three years' of exposure to elevated $\mathrm{CO}_{2}$, but is expected to hold after centuries of exposure. Factors which could affect this outcome include selection of ecotypes adapted to elevated $\mathrm{CO}_{2}$ and, interactions between potential photosynthate supply and nutrient supply (increased nutrient-use efficiency, nutrient uptake and sequestering, and nitrogen fixation). Other factors could reduce nutrient availability, such as decreasing litter quality. These contributing aspects will be studied as appropriate.

\section{Hypothesis 2: Ability of Eriophorum angustifolum to effectively utilize elevated atmospheric $\mathrm{CO}_{2}$ will be the result of genetic selection.}

Explanation. Selection will be for plants with greater sink strength and/or greater nutrient acquisition or nutrient-use efficiencies due to elevated atomospheric $\mathrm{CO}_{2}$. Under field and controlled-environmental growth conditions, plants from areas of elevated atmospheric $\mathrm{CO}_{2}$ will be better able to utilize elevated $\mathrm{CO}_{2}$ levels in photosynthesis. 
Hypothesis 3i The tundra in the Russian arctic and western Iceland is currently a source of $\mathrm{CO}_{2}$ to the atmosphere.

Explanation The tundra of the eastern central north slope of Alaska fias been a sink for carbon with respect to the atmosphere in the historic and recent geologic past. This area is now a source of $\mathrm{CO}_{2}$ to the atmosphere. This change appears to be due to a combination of increased temperature followed by a lowering of the soil moisture. Since warming has been reported for much of the circumpolar arctic, we anticipate that other arctic regions, including those in Iceland and Russia, have experienced a reduction in net ecosystem carbon uptake, or even a net loss to the atmosphere as is the case in central Alaska.

Hypothesis 4: Increased soil temperature will increase net ecosystem $\mathrm{CO}_{2}$ flux to the atmosphere in well-drained habitats and decrease net ecosystem flux to the atmosphere in flooded habitats.

Explanation. Decomposition of dead organic matter is primarily a function of temperature and the reduction-oxidation (redox) potential of the substrate. In arctic tundra ecosystems, soil temperatures are often too low for significant respiratory activity by soil microorganisms.

Increases in soil temperature will directly increase microbial activity, decomposition rates, and $\mathrm{CO}_{2}$ efflux. In addition, higher soil temperatures will also increase thaw depth which will increase soil aeration and the total amount of carbon available for decomposition. Decomposition will be stimulated more than net primary productivity. However, since the $\mathrm{C}: \mathrm{N}$ ratio of arctic plants is higher than arctic soils (Oechel and Billings, 1992), increased decomposition with elevated temperatures could result in more carbon accumulated above-ground than is released belowground, and the sink strength of the arctic could be increased.

In flooded habitats, the increase in temperature and thaw depth will not significantly affect the water balance of the site. Soil decomposition will continue to be limited by redox potential, and net primary productivity will be increased more than soil decomposition. As a result, the site will be a greater net $\mathrm{CO}_{2}$ sink with respect to the atmosphere. However, the prevailing waterlogged conditions, coupled with the increased soil temperature, will lead to higher rates of $\mathrm{CH}_{4}$ efflux.

\section{Hypothesis 5: Increased soil drainage will increase $\mathrm{CO}_{2}$ flux to the} atmosphere, especially in habitats of poor drainage and waterlogged soil conditions.

Explanation. Poor drainage (often due to or exacerbated by the presence of permafrost) creates water-logged conditions which reduces rates of aerobic respiration and decomposition. Increased drainage will result in better soil aeration, higher rates of decomposition, and higher rates of $\mathrm{CO}_{2}$ flux to the atmosphere. Plant productivity may increase due to greater nutrient availability and greater nutrient uptake capacity, but the increase in net primary productivity will be less than the increase in soil decomposition. Drainage in peat lands results in increased soil decomposition and high rates of $\mathrm{CO}_{2}$ loss to the atmosphere (Bramryd, 1979, 1980).

Hypothesis 6: Higher soil moisture will increase $\mathrm{CH}_{4}$ flux to the atmosphere and will increase carbon sequestering by the ecosystem, especially in habitats which have better drainage.

Explanation. $\mathrm{CH}_{4}$ production is an anaerobic process. Factors which reduce soil aeration tend to increase $\mathrm{CH}_{4}$ production. In habitats that have well-drained soils, $\mathrm{CH}_{4}$ production is low. If the drainage characteristics are altered enough to encourage anaerobiosis, $\mathrm{CH}_{4}$ production will increase. The opposite tends to be true for soil decomposition and $\mathrm{CO}_{2}$ production. Adding water 
in well-drained soils should decrease decomposition and increase net $\mathrm{CO}_{2}$ sequestering. In habitats that already have poor drainage, adding water should not significantly further reduce soil aeration and decomposition.

Hypothesis 7: The tundra of the eastern-central North Slope of Alaska is currently a source of $\mathrm{CO}_{2}$ (and $\mathrm{CH}_{4}$ ) to the atmosphere, the rate of which is accurately predicted by the additive fluxes observed at the plot scale. Incorporating all vegetation terrain units present will not alter the qualitative conclusions drawn from measurements of the dominant vegetation types at the plot scale (however, the magnitude of the fluxes may be refined).

Explanation. Arctic landscapes are a heterogeneous collection of vegetation terrain units with differing community composition, soil types, water balances, and thaw depths. Each of these variables affect carbon balance, resulting in a mosaic of $\mathrm{CO}_{2}$ and $\mathrm{CH}_{4}$ fluxes within a region that differ not only in rate but also potentially in direction. For example, the extensive chamber measurements made in a variety of habitat types during the 1990-91 sampling years indicate that the measurement sites were losing carbon to the atmosphere. Some habitats, however, were stronger sources than others, while others were, at times, slight sinks. The additive fluxes of these habitat types will determine the regional flux. More of the habitats measured were sources than were sinks, indicating that the tundra on a regional scale is a net source of carbon to the atmosphere. However, minor vegetation terrain units have not been measured, and consideration of these types may affect the calculation of the regional fluxes.

\section{Approach}

Long-term response of arctic plants and ecosystems to elevated atmospheric $\mathrm{CO}_{2}$

\section{Iceland}

Initial identification of $\mathrm{CO}_{2}$ evolving have been completed. During 1992, the temporal variability of the $\mathrm{CO}_{2}$ plume, temperature, $\mathrm{pH}$, sulfur dioxide concentration, humidity, nutrient availability, wind speed, wind direction, aspect, and soil moisture of each spring will be monitored. Two springs will then be isolated and used for intensive research during 1993, 1994, and 1995. Springs will be selected according to $\mathrm{CO}_{2}$ concentrations which bracket those anticipated over the next century, and which are not compromised by changes in other environmental factors. Physiological measurements will then be made at $\mathrm{CO}_{2}$ concentrations corresponding to possible future concentrations $(450 \mathrm{ppm}, 550 \mathrm{ppm}, 700 \mathrm{ppm}$, and $1000 \mathrm{ppm}$ ) and compared to data gathered from areas around mineral springs that do not emit $\mathrm{CO}_{2}$. Transplant experiments will be conducted to determine the extent of genetic variability. Ecosystem $\mathrm{CO}_{2}$ flux at various $\mathrm{CO}_{2}$ concentrations will also be determined. Populations exposed for long periods of time to various $\mathrm{CO}_{2}$ levels will be returned to controlled-environment growth chambers at SDSU to further test the genetic difference as they affect photosynthetic response to elevated atmospheric $\mathrm{CO}_{2}$. 


\section{Circumpolar patterns of net ecosystem $\mathrm{CO} 2$ flux}

\section{Russian Arctic}

Seasonal carbon balance studies will be initiated in the Taymyr Peninsula along a latitudinal transect similar to the one measured in Alaska (Oechel et al., submitted; Vourlitis et al., submitted). During the past two field seasons in arctic Alaska, $\mathrm{CO}_{2}$ flux was measured every 1 to 1.5 hours throughout a 24-hour diurnal cycle, every five to ten days using a LI-COR 6200 photosynthesis system and $0.75 \times 0.75 \mathrm{~m}$ "clap cuvette" described previously. Initially six replicate plots were used per measurement. It was thereby determined that four replicate plots per measurement were sufficient. During each diurnal measurement, gravimetric soil moisture and thaw depth will be determined within and outside each plot. Methane flux will be determined at the same locations and times by placing the chamber over the plot, sequentially removing gas samples over a 15-20 minute period, and determining the increase in chamber $\mathrm{CH}_{4}$ concentration by gas chromatography (Vourlitis et al., submitted,). Measurements will be made diurnally and seasonally along the Pura River of the Taymyr Peninnsula (Appendix II, Figs. 8 and 9).

\section{Iceland}

Seasonal net ecosystem $\mathrm{CO}_{2}$ fluxes will be determined at four $\mathrm{CO}_{2}$ gradients established around $\mathrm{CO}_{2}$ springs in Iceland (above). Measurement protocol will follow that used in Alaska.

\section{In situ controls of temperature and moisture on net ecosystem $\mathrm{CO}_{2}$ flux}

Soil temperature will be elevated through the use of Reemay TM fabric laid over the vegetation in four manipulation plots $(1.5 \times 1.5 \mathrm{~m}$ each). ReemayTM was found to be the most appropriate fabric for elevating temperatures in experimental plots (Marion, unpublished data). Another material may be used if found to have better qualities than ReemayTM and if adapted by NSF'S ITEX program (eg., Sun-LiteTM HP). Soil temperature will be monitored continuously using Type-T thermocouples and a Campbell Scientific CR21 Micrologger (Campbell Scientific, Inc., Logan, Utah) along with average, hourly weather data. Thaw depth in each manipulation plot will be determined during each sampling event. The effect of soil temperature on $\mathrm{CO}_{2}$ and $\mathrm{CH}_{4}$ flux will be determined using the sampling methods used during the 1990-91 sampling effort (Oechel et al., submitted; Vourlitis et al., submitted). Dr. Marion is continuing to evaluate approaches to modify temperatures, and our approach will vary to incorporate his new findings and those of NSF's ITEX program.

The water table will be decreased in four experimental plots at each site through the use of water wells with pumps to reduce water tables. Each water well will contain a float-activated water pump which will maintain the water level at the desired level. This level will be lowered through the growing season. Vertical cuts to the extent of the maximum seasonal thaw depth will be made and plastic barriers inserted to prevent water from entering the circumscribed plot. Areas with no observable water table (as may be the case at certain times for tussock tundra on a slope), will have precipitation restrained by rain exclusion shelters which will be erected during precipitation events to maintain soil water content approximately $30 \%$ below control values.

Water levels will be increased by pumping water onto the manipulation plots from local sources. Water will be kept from leaving the plots by use of plastic barriers as described above. Depending on the site, the goal will be to reduce the distance from the water table to the surface by $30 \%$ or increase the water content of the upper $10 \mathrm{~cm}$ by $30 \%$. In tussock tundra on a slope, vertical baffles cut into the permafrost to block or enhance flow will be erected as necessary. $\mathrm{CO}_{2}$ 
flux measurements will be made every 1 to 1.5 hours throughout a 24 -hour cycle once each six to ten days from snow melt to soil freeze-up.

Scaling of $\mathrm{CO}_{2}$ flux from plot, to landscape, to regional scales

The characterization of landscape heterogeneity is a central concern of investigations dealing with the scaling of ecological processes. Two types of spatial heterogeneity are defined by Philip (1980), namely, deterministic and stochastic heterogeneity. Deterministic heterogeneity refers to properties varying in a spatially known way, while stochastic heterogeneity relates to irregular spatial variability which is essentially random (Philip, 1980). Similarly, Avissar (1991) concluded that two types of spatial heterogeneities need to be considered in the representation of the earth's surface in climate models (landscape patchiness, and intra-patch variability). Spatial heterogeneity cannot be regarded as independent of the size of the area under investigation (Wetzel and Chang, 1988). The probability of greater variability increases as the area considered expands, and at some scale, deterministic variability may be included in the parameterization of stochastic variability.

In order to model or study the relationship between land-surface fluxes and the controlling process variables at different scales, it is necessary to make observations at a range of scales. The importance of this principle has been recognized by FIFE and BOREAS scientists in designing these two large experiments sponsored by NASA. A second requirement in such studies is the development of an appropriate scheme for characterizing the landscape heterogeneity (patch). The proposed field instrumentation and aircraft flux observations considered in our NSF proposal are consistent with the requirements for scaling from detailed plant observations to regional estimates of carbon fluxes. As part of the NSF proposal, we plan to use remotely-sensed imagery as the basic source of data for establishing the "deterministic" heterogeneity of the study area. The heterogeneity within these deterministic classes will then be treated as stochastic heterogeneity and may be described by a probability density function (PDF) of the variable of concern. If the variables are categorical (e.g. species), then relative proportions may be assigned to each deterministic class on a probabilistic basis.

The overall approach will be to measure $\mathrm{CO}_{2}$ and $\mathrm{CH}_{4}$ fluxes using three approaches: chamber (DOE, proposed here), tower-eddy correlation (NSF), and aircraft (NSF) which represent three spatial scales: plot, landscape, and mesoscale (McCauley and Meier, 1991). Methods for scaling will be developed and analyzed under the NSF-sponsored activities, and will include a statistical analysis of the contributing elements to measured fluxes, remote sensing to identify landscape variables that can be used to estimate state of activity, and modelling of ecosystems processes which affect trace gas fluxes of interest.

\section{Cooperative Research with NSF}

During the next three field seasons, we will be scaling up our plot level $\mathrm{CO}_{2}$ and $\mathrm{CH}_{4}$ flux measurements to a regional basis through a cooperative effort between a proposed NSF study and the DOE study proposed. According to our NSF ARCSS LAII proposal (Appendix III), NSF will sponsor the regional sampling effort, which consists of eddy correlation towers and aircraft measurements. The DOE research proposed here will quantify the contribution of various habitat types in the footprint of the tower and aircraft measurements in order to understand the contributions of these units to the airborne and tower measurements.

Towers will be run continuously at Prudhoe Bay in the north, and Happy Valley in the south during the period of aircraft measurements (NSF). The greatest concentration of chamber measurements will be in the areas of the towers, in order to document and understand the elements 
contributing to the signature derived by tower measurements over the area of the upwind footprint, and comparing this to a statistical sampling in the region of the tower. Chambers will also be deployed along the Haul Road. Data collection for remote sensing and GIS (NSF) will be concentrated along belt transects between Prudhoe Bay in the north, and Toolik Lake to the south, and between Barrow in the West, and ANWR (southeast of Barter Island) in the east.

Flight patterns for the NSF-sponsored aerodynamic flux measurements will include a " $t$ " sampling pattern from Barrow to ANWR and from Prudhoe Bay to Toolik Lake giving a $500 \mathrm{~km}$ transect from west to east, and a $200 \mathrm{~km}$ transect from north to south (Fig. 3). These flight lines will not be entirely straight. Rather, they will be developed to ensure adequate sampling of all significant landscape units of the area, and to include areas of past and current intensive research activities relevant to this study and will hopefully include DOE's ARM site. Other flight lines will be developed as weather and air time permit in order to maximize the spatial coverage of trace gas flux over arctic Alaska, including areas and vegetation types not previously measured.

During the 1993-1995 summers, field measurements of trace gas flux will be made within vegetation types (vegetation/surface feature types) which are thought to be contributing significantly to the measured $\mathrm{CO}_{2}$ flux at the landscape scale (tower) and mesoscale (aircraft). Plot measurement locations will be selected from the areas sampled by the aircraft and towers. We will also measure other, less dominant, vegetation types in order to obtain a statistical sampling of all vegetation types likely to be contributing significantly to the regional carbon flux. In addition, we will be measuring environmental variables (including light, temperature, depth to the water table, and soil moisture content), vegetation and soil properties (including leaf, stem, belowground biomass, and soil organic matter content), and processes (i.e. gross ecosystem productivity (GPP), ecosystem respiration, and net ecosystem $\mathrm{CO}_{2}$ flux) needed to model the patterns of and controls on $\mathrm{CO}_{2}$ flux.

We envision about 5-10 (possibly up to 15 depending on the area studied) vegetation/surface types to be sampled around each tower location. Each type will be replicated four times. Measurements will be made every 1 to 1.5 hours throughout the 24-hour measurement period. Sampling location will be determined by the wind direction and tower footprint at the time of measurement in order to sample the area contributing to the tower measurement. Similarly, sampling will be carried out along the flight line corresponding to the location of footprint primarily contributing to the aircraft measurement of trace gas flux and vegetation-surface feature indices. Measurements of plot trace gas flux $\left(\mathrm{CO}_{2}\right.$ and $\left.\mathrm{CH}_{4}\right)$ will be conducted as previously described (Oechel et al., submitted; Vourlitis et al., submitted). Diurnal measurements (replicated four times each) will be taken every hour throughout the day to correspond with tower and aircraft observations. Methane flux will be determined each hour during the course of $\mathrm{CO}_{2}$ flux determinations using a gas chromatograph and samples drawn from separate chambers (Vourlitis $e t$ al., submitted). Extensive sites will receive less frequent monitoring, and instantaneous values will be compared to seasonal patterns developed for the intensive sites.

Measurements over the last two years concentrated on the dominant vegetation types in tussock and wet coastal tundra ecosystems. There are, however, a variety of other habitat types within these ecosystems. For example, tussock tundra ecosystems have water tracks and lichen heath habitats which have markedly different vegetation, soil moisture, soil temperature, and thaw depth. As a result, $\mathrm{CO}_{2}$ and $\mathrm{CH}_{4}$ flux is probably quite different compared to the dominant tussock tundra habitats. If time permits, we plan to expand our measurements to incorporate these different habitat types, which will allow us to characterize the carbon balance of complete ecosystems.

If time permits, we propose to measure $\mathrm{CO}_{2}$ and $\mathrm{CH}_{4}$ flux in Barrow, Alaska. Tower measurements (NSF) will take place at the IBP site-2 during the 1995 sampling year, while chamber measurements (DOE) will take place in the tower footprint to quantify the contribution of 
different habitat types to the regional flux. The Barrow area offers a variety of wet coastal tundra ecosystem types. In addition, temperature records taken over the last 70 years indicate that surface temperatures during the summer months (June-August) have increased by approximately $1.5^{\circ} \mathrm{C}$ over the last 10 years, suggesting that global warming may already be occurring in this region (Oechel et al., submitted). Wet coastal tundra ecosystems in the Barrow region were sampled intensively during the U.S. IBP effort of the 1970's, and thus offer historical baseline data that can be used to determine the effect of climate change on the $\mathrm{CO}_{2}$ and $\mathrm{CH}_{4}$ balance of wet coastal tundra ecosystems. We sampled several sites in Barrow over a 10-day period during the 1991 sampling season, and found that the IBP site-2 was no longer a sink for atmospheric $\mathrm{CO}_{2}$. Our goal in Barrow is to sample these same sites to determine whether the wet coastal tundra sites in this region are consistent sources of atmospheric $\mathrm{CO}_{2}$ and $\mathrm{CH}_{4}$.

Iceland

\section{Locations}

Icelandic mineral springs have existed for millennia. Many of them emit $\mathrm{CO}_{2}$ to various degrees from either mantel, carbonate mineral, or decaying organic matter (Barnes et al., 1978). Most of the mineral springs throughout the world have been disturbed; the hot ones used as mineral baths and health spas, and the cold, very $\mathrm{CO}_{2}$-rich ones for mineral water and carbonating soft drinks. The mineral springs on the Sneffesenss peninsula of Iceland, however, are relatively undisturbed and have not been exploited for these purposes as they are too remote and have too little flow to be profitable. Vallnabnickur Spring is a 90 -minute walk into the mountains from a rarely traveled road between the fishing villages of Olafsvik and Grundarfjordur. Other springs like Raudamels, Olafsvik, Bjarnarfossot, Grundarfjordur, and Osakot are an easy five to tenminute walk, and still have natural arctic vegetation growing around them. This vegetation has been exposed to elevated levels of $\mathrm{CO}_{2}$ for thousand of years. There is a cold mineral spring near Lysuhol whose water chemistry is similar in chemical composition and $\mathrm{CO}_{2}$ content to that from precipitation (Arnorsson and Barnes, 1983) which could be used as a control.

\section{Russian Arctic: Taymyr Peninsula}

Research will be conducted on the Taymyr Peninsula in north-central Russia (Appendix II, Fig. 8). This area is ideal for the research proposed for several reasons. First, every habitat type found in arctic ecosystems (from arctic desert to southern tundra) is found in the region. Secondly, Russian scientists have worked extensively in this region in the past. Data on vegetation types, soil $C$ stores, and weather are quite complete, so the physical and biological characteristics of the site are well known. Thirdly, Russian scientists have set up base camps at some of the proposed research sites (Pura River, Appendix II, Fig. 9) that are equipped with housing, food, and fuel facilities. Finally, transportation can be provided by helicopter and motor boat at significantly lower cost compared to U.S. equivalents.

Research sites on the Taymyr Peninsula are run by the Institute of Far North Agriculture, Siberian Subdivision of the Russian Academy of Sciences, and are supported by Moscow State University. We have established contacts through Moscow State University with Drs. Tagir Gilmanov and Victor Nosov, who are also collaborating scientists in the proposed NSF and DOE research (curricula vitae, Appendix III). There are six possible sites in the region where measurements of $\mathrm{CO}_{2}$ and $\mathrm{CH}_{4}$ flux would be carried out. Various research projects have been conducted at all sites by Russian scientists in the past. The following are proposed research sites on the Taymyr Peninsula (Appendix II, Fig. 9).

1. Pura Site $\left(72^{2} 30^{\prime} \mathrm{N}, 85^{\circ} 40^{\prime} \mathrm{E}\right)$. This site is well supplied with long-term information on weather, vegetation, and soil characteristics, and includes most of the relief elements of the Western Taymyr. There are a total of 240 vascular plant species, and 10 main tundra 
habitat types with widely varying soil moisture, topographical, and community characteristics.

2. Ust-Tareya Site $\left(72^{2} 40^{\prime} \mathrm{N}, 91^{\circ} 30^{\prime} \mathrm{E}\right)$. This site is similar to the Pura site. It is also well documented with long-term information about vegetation, soil type, and climate. Tussock tundra is the most prominent vegetation at this site.

3. Agapa Site (7130'N, 8850'E). Well-documented, long-term records and information on soil type, vegetation, and climate are available for this site. This site is the northern limit of the south shrub tundra, and has 244 species of vascular plants. In addition, there is a soil moisture and tundra habitat gradient that is oriented perpendicular from the Pyasina River which is adjacent to the site.

In addition to these sites, there are three other sites of interest which have received less research attention, but still have well-documented information on vegetation, soil, and climate characteristics. South of the Agapa site and north of Lake Pysina lies a site along the Pysina River. This site is similar to the Agapa site, but has more elements of southern shrub tundra than the Agapa site. Another site is located north of the Pura site, near the town of Mys Khodnoy, which is near the mouth of the Pyasina River and located on the coast of the Arctic Ocean. Finally, the last site is near the town of Dikson which is also located on the coast of the Arctic Ocean, approximately $150 \mathrm{~km}$ west of the Mys Khodnoy site. Climate data at this site has been collected since 1916, so there are extensive records on monthly temperature and precipitation for over 75 years that are available.

\section{Alaska: Manipulations}

The manipulative experiments as well as the sampling of various other habitats within the broad categories of tussock tundra and coastal tundra will be carried out at Happy Valley and Prudhoe Bay (both wet and dry coastal tundra sites). In addition to the fact that all sites have been extensively sampled for seasonal carbon balance in 1990 and 1991, Happy Valley and Prudhoe Bay are established logistic locations. Temperature treatments are planned at Toolik Lake and Barrow, Alaska as part of the NFS-funded International Tundra Experiment (ITEX). These additional site locations will be monitored if the project is funded.

\section{Alaska: Scaling}

The flight center will be based at Prudhoe Bay, Alaska. This site offers extensive wet coastal tundra vegetation, indoor heated hanger space, ample accommodations for the scientific and flight crews, access to the Haul Road transect along which there is ample data, and from which chamber measurements will continue to be made, and access to other areas of interest including Barrow. The back-up location for staging is Barrow.

Flight patterns will include a " $\mathrm{t}$ " sampling pattern from Barrow to ANWR and from Prudhoe Bay to Toolik Lake giving a 500-km transect from west to east, and a 200-km transect from north to south (Fig. 3 and described above). 


\section{Tasks}

TASK 1: LONG-TERM RESPONSE TO ELEVATED ATMOSPERIC $\mathrm{CO}_{2}$

a) Select transects, monitor $\mathrm{CO}_{2}$ environment

b) Collect ecophysiological data: Ps, Rs, A:Ci curves of PS, conductance, and transpiration

c) Measure biomass, LAI, species composition, phenology data, and collect tissue samples from along transects

d) Analyze tissue samples for $\mathrm{TNC}, \mathrm{C} / \mathrm{N}$ ration, ${ }^{12} \mathrm{C} /{ }^{13} \mathrm{C}, \mathrm{RuBp}$

e) Measure whole-net ecosystem $\mathrm{CO}_{2}$ flux over $\mathrm{CO}_{2}$ gradient

f) Reciprocal transplants made and initiate collection of ecophysiological data

g) Controlled-environment studies of $\mathrm{CO}_{2}$ ecotypes to $\mathrm{CO}_{2}$ concentrations

TASK 2: $\quad$ CIRCUMPOLAR NET ECOSYSTEM $\mathrm{CO}_{2}$ FLUX

Russian/Icelandic arctic:

a) Identify sites to make-up transect

b) Measure seasonal whole-ecosystem $\mathrm{CO}_{2}$ flux along transect

c) Validate data using additional sites along transect

TASK3: IN SITU CONTROLS BY TEMPERATURE AND MOISTURE ON NET ECOSYSTEM CO 2 FLUX

a) Construct and test equipment to modify water and temperature of tundra

b) Select and prepare sites sites for manipulations and carbon flux monitoring

c) Monitor physical and biological (carbon flux) effects of treatments

TASK 4: $\quad$ SCALING OF ECOSYSTEM FLUX MEASUREMENTS FROM PLOT TO LANDSCAPE /REGIONAL AND CIRCUMPOLAR

a) Select and measure varying habitats at plot level

b) Correlate tower measurements with plot measurements

c) Make plot measurements along aircraft flight lines and tower locations and correlate results

\section{TASK 5: $\quad$ PROJECT SYNTHESIS}

a) Data analysis and evaluation of methods

b) Calculate estimates for current annual carbon flux for three major arctic regions studied.

c) Predict sensitivity of carbon flux in arctic to likely scenarios of global change from regions studies using field, manipulations, transplants and long-term data sets 


\section{TIMELINE}

_=Alaska, $X=$ Russia, $+=$ Iceland -

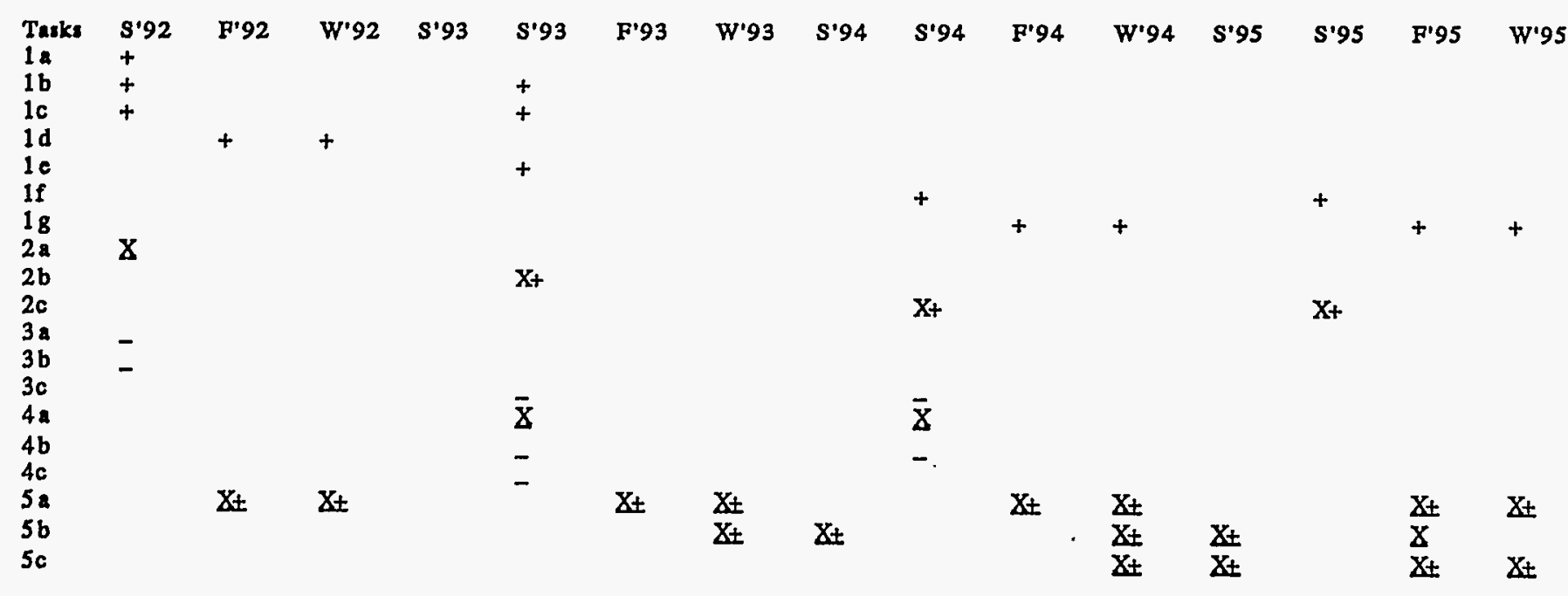




\section{INSTITUTIONAL CAPABILITIES}

General arctic research: San Diego State University has a history of more than 25 years of ecological studies in the arctic and a strong continuing commitment to arctic research. SDSU faculty were involved in DOE's Project Chariot studies at Cape Thompson, Alaska in the early 1960 's, probably the first terrestrial arctic systems study in the U.S. These and other faculty were involved in follow-up studies at Cape Thompson funded by DOE. SDSU faculty were major participants in experimental studies and modelling of ecosystem function at Barrow, Alaska as part of the U.S. IBP. Major arctic and boreal forest research programs have been conducted by SDSU faculty and funded by sections of DOE and by NSF. The recent past academic vice president of SDSU (and Adjunct Professor in Biology) is the current president of ARCUS (the Arctic Research Consortium of the United States) and has more than 25 years experience in the arctic.

General Institutional Capabilities: SDSU provides the faculty, library, equipment, and physical facilities of a modern large university of more than 31,000 students. SDSU has recently been considered one of the ten best comprehensive universities in the west according to surveys conducted by U.S. World Report.

Arctic Ecosystem Function, Ecophysiology, and Climate Change Capabilities: Dr. Oechel has been conducting research on arctic ecosystem function, ecophysiology, and effects of global change for over 20 years. He has available a modern laboratory including most equipment required for conducting the research proposed. This includes infrared gas analysis systems and specialized cuvettes for measuring $\mathrm{CO}_{2}$ flux of plants and ecosystems under ambient and modified environmental conditions, gas chromatographs, and chambers for measuring rates of methane production, time domain reflectometer, thermocouple psychrometers, and pressure bombs for measuring soil and plant water status, LI-COR leaf area meters, Macintosh, IBM, and HP (Model 300 and 9816) personal and minicomputers, as well as standard laboratory equipment (balances, ovens, grinders, etc.). The Ecology program area of the Department of Biology maintains a analytical lab for determination plant and soil nutrient content.

Grant administration: Grants and contracts are administered by the SDSU Foundation, a non-profit auxiliary of SDSU. The Foundation handles accounting, billing, purchasing, personnel, and related items.

\section{RELATIONSHIP TO PAST RESEARCH}

This proposed research builds on past research funded by DOE and NSF, including the DOE $\mathrm{CO}_{2}$ program and the NSF IBP program.

Work on Iceland $\mathrm{CO}_{2}$ springs is a logical extension to the in situ $\mathrm{CO}_{2}$ manipulations conducted at Toolik Lake. In these studies, leaf photosynthesis and net ecosystem photosynthesis adjusted to elevated atmospheric $\mathrm{CO}_{2}$ within weeks to months. However, longer-term processes, including ecotypic differentiation, population responses, compositional changes, and altered nutrient status could affect and potentially increase the ecosystem's ability to utilize elevated atmospheric $\mathrm{CO}_{2}$ (Oechel and Billings, 1992; Fig. 1.5). However, this aspect could not be tested in experiments lasting only a few years.

Work in Iceland and Russia on the net ecosystem carbon balance extend the observations made on the north slope of Alaska. Measurements made at Barrow, Alaska, will allow comparison to rates determined during IBP, and document any changes which may have occurred in response to warming since that time. 
Proposed manipulations of temperature and moisture in the field build on the past observations of recent changes in net ecosystem carbon flux, apparently in response to recent warming and drying in the arctic. These manipulations will allow us to better understand controls on $\mathrm{CO}_{2}$ and $\mathrm{CH}_{4}$ flux in moist and wet arctic ecosystems.

This research, in conjunction with NSF funding, will extend past plot and site research to the large scale. It builds on and benefits from several decades of plot measurements and understanding funded by IBP, other NSF programs, and several DOE programs to take the next steps of moving to landscape and mesoscales. It is intended to set the stage for moving to the global scale (McCauley and Meier, 1991).

\section{INTERAGENCY COOPERATION}

This research will benefit from and aid studies conducted by other agencies and from interagency cooperation. The scaling portion of this research including plot measurements of $\mathrm{CO}_{2}$ flux in Alaska, are intended to strongly interface with research proposed to NSF's ARCSS LAII program entitled "Large area estimates of carbon fluxes in arctic landscapes" (abbreviated in Appendix III).

Access of the Research Council of Canada Twin Otter aircraft for measurement of trace gas flux is of exceptional importance to this project and to our ability to measure and estimate mesoscale trace gas fluxes. Salary costs for collecting and analyzing the aircraft-collected data will be contributed by participating agencies of the Canadian and Provincial governments. The Canadian agencies will have eight people (pilot, aircraft mechanic, two instument technicians, an NRC scientist, an agricultural scientist, a University scientist, and an electronic engineer/ programmer) on site for 28 days. The contribution of the Canadian government to this project is estimated to be in excess of $\$ 200,000$ U.S.

The North Slope Borough and ARCO are making significant contributions to our research. Hotel accommodations and food are furnished for project scientists at Prudhoe Bay. Accommodations including sleeping and cooking facilities are provided at no charge to graduate students at Barrow. These in-kind contributions for the project proposed, represent a significant cost savings for the project conservatively estimated at approximately $\$ 75,000-100,000 /$ year.

We are aware of and will interact with other successful programs being proposed to ARCSS. Potential interactions include, but are not limited to, studies of controls on and patterns of methane production and oxidation (Peterson et al.), surface energy balance and energy dynamics (Kane et al.), permafrost carbon and peat content and potential for release (Ping), and soil carbon content and permafrost dynamics (Brown and Everett).

Manipulation plots of altered soil temperature and season length, if established as part of NSF's International Tundra Experiment ITEX by Marion (Walker, Marion, et al., 1992), will be used in this project to observe effects on trace gas flux, and will extend and enhance observations and manipulations being conducted by this proposed project.

The National Park Service has indicated a desire in funding a project to determine the flux of carbon in northern ecosystems over a chronosequence between fires. If funded, this NPS project will add another dimension (stand age) to the studies carried out to date.

\section{EXPECTED SIGNIFICANCE}

Past DOE-funded research indicated that elevated $\mathrm{CO}_{2}$ had no effect on ecosystem carbon balance after three years. Longer time periods were not investigated. However, over longer-time 
scales, ecosystem processes may occur which will allow a response to elevated $\mathrm{CO}_{2}$. This has obvious relevance to our ability to predict the effects of elevated atmospheric $\mathrm{CO}_{2}$ and climate change on arctic ecosystems. Manipulations proposed here will increase our understanding of the mechanisms involved in controlling $\mathrm{CO}_{2}$ and $\mathrm{CH}_{4}$ flux, and will increase our ability to predict the effect of various combinations of factors on ecosystem carbon flux.

Arctic tundra and other boreal regions contain large amounts of carbon in the soil active layer and frozen in the peat. If global warming causes a net release of carbon to the atmosphere, a very strong positive feedback could result. Recent research results (Oechel et al., 1991a,b) and Oechel et al., submitted, Grulke et al., 1990; Oechel and Billings, 1992) indicate that the north slope of Alaska south of Prudhoe Bay has recently shifted from a system of long-term carbon accumulation to one of carbon loss. This change is likely due to recent climatic patterns (Oechel et $a l$., submitted) and may be a harbinger of effects of global change on arctic ecosystems. The research proposed in this application will allow us to evaluate the generality of the observed results. The initial step will be to estimate the mesoscale carbon balance of arctic tundra on the north slope of Alaska based on measurements made at several scales (plot, landscape, and mesoscale). It will also develop methods of scaling plot measurements to landscape and regional scales, or of efficiently estimating large-scale trace gas fluxes using various inputs including indices derived from remotely-sensed data. These methods and approaches should be of significance for continuation of carbon flux estimate throughout Alaska and the circumpolar arctic. They should also be helpful in extrapolating other ecosystem processes to larger regional scales. We will also make direct measurements of current $\mathrm{CO}_{2}$ flux in other circumpolar regions including Russia and Iceland.

\section{LITERATURE CITED}

Arnorsson, S. and I. Barnes. 1983. The nature of carbon dioxide waters in Snaefellsnes, Western Iceland. Geothermics. 12:(2)171-176.

Avissar, R. 1991. A statistical-dynamic approach to parameterize subgrid-scale land-surface heterogeneity in climate models. Surveys in Geophysics. 12: 155-178.

Barnes, I., W.P., Irwin, and D.E., White. 1978. Global distribution of carbon-dioxide discharges and major zones of seismicity, U.S. Geological Survey Water-Resources Investigations Open-File Report 79-39, 12p.

Bazzaz, F.A. 1990. The response of natural ecosystems to the rising global $\mathrm{CO}_{2}$ levels. Annu. Rev. Ecol. Syst. 21: 164-196.

Billings, W.D., J.O. Luken, D.A. Mortensen, and K.M. Peterson. 1982. Arctic tundra: A source or sink for atmospheric carbon dioxide in a changing environment? Oecologia. 52: 7-11.

Billings, W.D., J.O. Luken, D.A. Mortensen, and K.M. Peterson. 1983. Increasing atmospheric carbon dioxide: Possible effects on arctic tundra. Oecologia. 58: 286-289.

Billings, W.D., K.M. Peterson, J.O. Luken, and D.A. Mortenson. 1984. Interaction of increasing atmospheric carbon dioxide and soil nitrogen on the carbon balance of tundra microcosms. Oecologia. 65: 26-29.

Billings, W.D. and K.M. Peterson. 1992. Some possible effects of climatic warming on arctic tundra ecosystems of the Alaskan North Slope. Chapter 17. In: Consequences of the Greenhouse effect for Biological Diversity. R.L. Peters and T. Lovejoy (eds). Yale University Press, New Haven, Connecticut, USA. (in press).

Bramyrd, T. 1979. The effects of mano on the biogeochemical cycle of carbon in terrestrial ecosystems. In "The Global Carbon Cycle" (B. Bolin, ed.), pp. 183-218. Wiley, New York.

Bramyrd, T. 1980. Effect on the carbon cycle due to human impact on forest ecosystems. In "Biogeochemistry of Ancient and Modern Environments" (P.A. Trudinger, M.R. Walter, B.J. Ralph, eds.), pp. 405-412. Springer-Verlag, New York. 
Chapin, F.S., II, P.C. Miller, W.D. Billings, and P.I. Coyne. 1980. An arctic ecosystem, the coastal tundra at Barrow, Alaska. In: J. Brown, P.C. Miller, L.L. Tieszen, and F.K. Bunnell, (eds.). Dowden, Hutchinson, and Ross, Stroudsburg, PA. pp. 458-482.

Clymo, R.S. 1984. The limits of peat bog growth. Philosophical Transactions of the Royal Society of London. 303: 605-654.

Coyne, P.I. and J.J. Kelley. 1975. $\mathrm{CO}_{2}$ exchange over the Alaskan arctic tundra: meteorological assessment by an aerodynamic method. J. Appl. Ecol. 12: 587-611.

Desjardins, R.L., J.I. MacPherson, P.H. Schuepp, and F. Karanja. 1989. An evaluation of airborne eddy flux measurements of $\mathrm{CO}_{2}$, water vapor and sensible heat. Boundary-Layer Meteorol. J. 47: 55-69.

Desjardins, R.L., H. Hayhoe, J.I. MacPherson, and P.H. Schuepp. 1990a. Regional estimates of gas transfer using an airborne system. Air-water mass transfer. Minneapolis, Minnesota. pp. 230-233.

Desjardins, R.L., P.H. Schuepp, and J.I. MacPherson. 1990b. Spatial and temporal variation of $\mathrm{CO}_{2}$, sensible and latent heat fluxes over the FIFE site. Proceedings of the American Meteorological Society. Anaheim, California. pp. 45-50.

Gorham, E. 1991. Northern peat lands: Role in the carbon cycle and probable responses to climate warming. Ecological Applications. 1: 182-195.

Grulke, N.E., G.H. Riechers, W.C. Oechel, U. Hjelm, and C. Jaeger. 1990. Carbon balance in tussock tundra under ambient and elevated atmospheric $\mathrm{CO}_{2}$. Oecologia. 83: 485-494.

Hengeveld, H. 1991. Understanding atmospheric change: A survey of the background science and implications of climate change and ozone depletion. A State of the Environment Report, No. 91-2. Atmospheric Environment Service, Environment Canada.

Kling, G.W., G.W. Kipphut, and M.C. Miller. 1991. Arctic lakes and streams as gas conduits to the atmosphere: Implications for tundra carbon budgets. Science. 251:298-301.

Kimball, B.A., J.R., Mauney, J.W., Radin, F.S., Nakayama, S.B., Idso, D.L., Hendrix, D.H. Akey, S.G., Allen, M.G., Anderson, and W., Hartung. 1986. Effects of increasing atmospheric $\mathrm{CO}_{2}$ on the growth, water relations, and physiology of plants grown under optimal and limiting levels of water and nitrogen. In "Response of Vegetation to Carbon dioxide 039." U.S. Department. of Energy, Office of Energy Research, Washington, DC.

Kramer, P.J. 1981. Carbon dioxide concentration, photosynthesis, and dry matter production. BioScience 31: 29-33.

Lachenbruch, A.H., T.T. Cladouhos, and R.W. Saltus. 1988. In: Permafrost Temperature and the Changing Climate. Proceedings of the 5th International Conference on Permafrost, Trondheim, Norway. pp. 1-9.

Lachenbruch, A.H. and B.V. Marshall. 1986. Changing climate: Geothermal evidence from permafrost in the Alaskan arctic. Science. 234: 689-696.

McCauley, L.L. and M.F. Meier. ARCTIC SYSTEM SCIENCE, Land/Atmospheric/Ice Interactions - A Plan for Action. Based on a workshop organized by the Arctic Research Consortium of the U.S., Boulder, Colorado, February 26 - March 3, 1990. 48 pp.

Melillo, J.M., Callaghan, T.V., Woodward, F.I., Salati, E. and S.K. Sinha. 1990. Ch. 10: Effects on Ecosystems. In: Houghton, J.T., Jenkins, G.C. and J.J. Ephraums (eds.) Climate Change. The IPCC Scientific Assessment. Cambridge University Press, Cambridge. $365 \mathrm{pp}$.

Miller, P.C. (ed.) In: Carbon Balance in Northern Ecosystems and the Potential Effect of Carbon Dioxide-Induced Climate Change (CONF-800033118), Report of a Workshop, San Diego, California, 7-9 March, 1980. Carbon Dioxide Effects Research and Assessment Program, U.S. Department of Energy, Washington, D.C. (NTIS, Springfield, Virginia, 1981).

Miller, P.C., R. Kendall, and W.C. Oeche1. 1983. Simulating carbon accumulation in northern ecosystems. Simulation. 40: 119-131. 
Mitchell, J.F.B., S. Manabe, V. Meleshko, and T. Tokioka. 1990. In: Climate Change: The IPCC Scientific Assessment World Meteorological Organization/United Nations Environment Programme. Intergovernmental Panel on Climate Change. pp. 131-172.

Mooney, H.A., B.G. Drake, R.J. Luxmoore, W.C. Oechel, and L.F. Pitelka. 1991. Predicting ecosystem responses to elevated $\mathrm{CO}_{2}$ concentrations. BioScience. 41: 96-104.

Oberbauer, S.F., N. Sionit, S.J. Hastings and W.C. Oechel. 1986. Effects of $\mathrm{CO}_{2}$ enrichment and nutrition on growth, photosynthesis and nutrient concentration of Alaskan tundra plant species. Can. J. Bot. 64:2993-2998.

Oechel, W.C., M. Jenkins, S.J. Hastings, G. Vourlitis, N. Grulke, and G. Riechers. 1991a. Effects of recent and predicted global change on arctic ecosystems. Abstract, Bull. Ecol. Soc. 72: 209.

Oechel, W.C., M. Jenkins, S.J. Hastings, G. Vourlitis, and G. Marion. 1991b. Recent Climate Change and Interaction with Carbon Balance of the Arctic Tundra. Suppl. EOE Transactions, American Geophysical Union. Vol. 72, No. 44, p. 70.

Oechel, W.C. and W.D. Billings. 1992. Effects of global change on the carbon balance of arctic plants and ecosystems. In: T. Chapin, R. Jeffries, J. Reynolds, G. Shaver, and J. Svoboda (eds.). Arctic Physiological Processes in a Changing Climate. Academic Press. pp. 139-167.

Oechel, W.C., M. Jenkins, S.J. Hastings, N. Grulke, and G. Vourlitis. 1992. The changing carbon balance of arctic tundra ecosystems: First evidence of climatic feedbacks on the global carbon cycle. Science. (submitted).

Oechel, W.C. and G.H. Riechers. Impacts of increasing $\mathrm{CO}_{2}$ on natural vegetation, particularly the tundra. Proceedings of Climate-Vegetation Workshop, NASA/Goddard Space Flight Center, Greenbelt, Maryland, January 27-29, 1986. pp. 36-42.

Oechel, W.C., G. Riechers, W.T. Lawrence, T.I. Prudhomme, N. Grulke, and S.J. Hastings. 1992. 'CO $2 \mathrm{LT}^{\text {' }}$ an automated, null-balance for studying the effects of elevated $\mathrm{CO}_{2}$ and global climate change on unmanaged ecosystems. Functional Ecology. 6: 86-100.

Oechel, W.C. and B. Strain. 1985. Response of native species and ecosystems. In: Direct Effects of Increasing Carbon Dioxide on Vegetation. Department of Energy DOE/ER0238.

Philip, J.R. 1980. Field heterogeneity: Some basic issues. Water Resources Research. 16: 443448.

Post, W.M. 1990. Report of a workshop on climate feedbacks and the role of peat lands, tundra, and boreal ecosystems in the global carbon cycle. ORNL/TM-11457, Oak Ridge National Laboratory, Oak Ridge, TN. 32 pp.

Schell, D.M. 1983. Carbon-13 and carbon-14 abundance in Alaskan aquatic organisms: Delayed production from peat in arctic food webs. Science. 219: 1068-1068.

Schell, D.M. and P.J. Ziemann. 1983. Accumulation of peat carbon in the Alaska arctic coastal plain and its role in biological productivity. In: Permafrost, Fourth International Conference Proceedings, Washington, D.C. National Academic Press. pp. 1105-1110.

Schlesinger, M.E. and J.F.B. Mitchell. 1987. Climate model simulations of the equilibrium climatic response to increased carbon dioxide. Reviews of Geophysics. 25: 760-798.

Shaver, G.R., and F.S., Chapin III. 1980. Response to fertilization by various plant growth forms in an Alaskan tundra: Nutrient accumulation and growth. Ecology 61: 662-675

Silvola, J. 1986. Carbon dioxide dynamics in mines reclaimed for forestry in eastern Finland. Ann. Bot. Fenn. 23: 59-67.

Tans, P., I. Fung, and T. Takahashi. 1990. Observational constraints on the global atmospheric $\mathrm{CO}_{2}$ budget. Science. 247: 1431-1439.

Tissue, D.L. and W.C. Oechel. 1987. Physiological response of Eriophorum vaginatum to field elevated $\mathrm{CO}_{2}$ and temperature in the Alaskan tussock tundra. Ecology. 68: 401-410.

Vourlitis, G.L., W.C. Oechel, S.J. Hastings, and M.A. Jenkins. The effect of soil moisture and thaw depth on methane flux from wet coastal tundra ecosystems on the north slope of Alaska. Chemosphere. (submitted). 
Wetzel, P.J. and J.T. Chang. 1988. Concerning the relationship between evapotranspiration and soil moisture. Journal of Climate and Applied Meteorology. 48: 305-315. 


\section{CURRENT AND PENDING SUPPORT}




\section{Current Support}

Funding Source: Project Title:

Award Amount: Period Covered: $\%$ Effort:

Location:

Funding Source: Project Title:

Award Amount: Period Covered: \% Effort:

Location:

Funding Source:

Project Title:

Award Amount: Period Covered:

\% Effort:

Location of Research:

Funding Source:

Project Title:

Award Amount: Period Covered \% Effort:

Location of Research:

Funding Source: Project Title:

Award Amount: Period Covered: \% Effort:

Location:

\section{Pending Support:}

Funding Source: Project Title:

Award Amount: Period Covered: $\%$ Effort: Location of Research:
Walter C. Oechel

Water Resource Center, University of California, Riverside "Effects of Global Climate Change and Increased Atmospheric $\mathrm{CO}_{2}$ on Water Use and Productivity of Mediterranean-type Ecosystems" $\$ 20,000$

$7 / 1 / 91-6 / 30 / 92$

$10 \%$

California

U.S. Department of Energy

"Response of a Tundra Ecosystem to Elevated Atmospheric Carbon Dioxide and $\mathrm{CO}_{2}$-Induced Climate Change"

$\$ 300,000$

$9 / 1 / 91-8 / 31 / 92$

$25 \%$

Alaska and California

The United States-Spanish Joint Committee for Cultural and Educational Cooperation

"Factors and Mechanisms Controlling Postfire Resprouting of Spanish and Mediterranean-type Shrubs"

$\$ 8,250$

$12 / 1 / 90-11 / 30 / 93$

$5 \%$

Spain and California

Westem Regional Center, National Institute for Global Environmental Change "Effects of Global Climate and Atmospheric Change on the Structure and Function of Mediterranean Shrub Ecosystems and Associated Forest Ecotones in California"

\section{$\$ 78,654$}

$7 / 1 / 91-6 / 30 / 92$

$15 \%$

California

Southem California Edison

"Effects of Global Climate and Atmospheric Change on the Structure and Function of Mediterranean Shrub Ecosystems and Associated

Forest Ecotones in California"

$\$ 48,640$

$4 / 1 / 92-3 / 31 / 93$

$10 \%$

California

Westem Regional Center, National Institute for Global Environmental Change "Effects of Global Climate and Atmospheric Change on the Structure and Function of Mediterranean Shrub Ecosystems and Associated Forest Ecotones in California"

$\$ 136,962$

$7 / 1 / 92-6 / 30 / 93$

$15 \%$

California 
Funding Source: Project Title:

Award Amount: Period Covered: \% Effort:

Location of Research:

Funding Source:

Project Title:

Award Amount:

Period Covered:

\% Effort:

Location of Research:

Funding Source:

Project Title:

Award Amount:

Period Covered:

\% Effort:

Location of Research:
Department of Interior - Interior Fire Coordinating Committee

"Net Ecosystem Carbon Flux of Age-specific Subarctic Tussock Tundra Stands

Following Fire: Implications for Alaska Interagency Fire Management"

$\$ 753,300$

$11 / 1 / 91-10 / 31 / 94$

$35 \%$

Alaska, California

NSF, ARCSS LAII

"Large Area Estimates of Carbon Fluxes in Arctic Landscapes"

$\$ 2,050,176$

$7 / 1 / 92-12 / 31 / 95$

$25 \%$

Alaska, SDSU

U.S. Department of Energy

"Response of a Tundra Ecosystem to Elevated Atmospheric Carbon Dioxide and $\mathrm{CO}_{2}$-induced Climate Change"

$\$ 1,051,864$

$9 / 1 / 92-8 / 31 / 95$

$25 \%$

Alaska and California 


\section{BUDGETS AND BUDGET JUSTIFICATION}

Ramoved at 
ABBREVIATED CURRICULUM VITAE 


\section{CURRICULUM VITAE}

Name: $\quad$ Walter C. Oechel

Education:

1966

1967

A.B., San Diego State University, San Diego, California, 1966.

$1969-1970$

Organization for Tropical Studies, Tropical Ecology Course, Costa Rica,

1970

Summer 1967.

Duke University, 1969-1970, Predoctoral Research.

Selected Professional Experience:

1983-date

1982-1987

1980-1987

1978-1982

1970-1978

\section{Selected Research Experience:}

1991-1992

1990-1992

1989-1992

1985-1988

$1984-1988$

$1982-1988$

1982-1984

\section{Selected Other:}

1987-

$1989-$

1991-
Professor, Biology Department, San Diego State University.

Director, Systems Ecology Research Group, San Diego State University.

Director, Biological Field Stations, San Diego State University.

Research Professor, Systems Ecology Research Group, San Diego State University.

Assistant-Associate Professor, Biology Department, McGill University. Tenured 1978.

Principal Investigator, WESTGEC "Effects of global climate and atmospheric change on the structure and function of Mediterranean shrub ecosystems and associated forest ecotones in California." July 1, 1991-June 30, 1992.

Principal Investigator, Southern California Edison, "Effects of global climate and atmospheric change on the structure and function of Mediterranean shrub ecosystems and associated forest ecotones in California." July 1, 1990-December 31, 1991.

Principal Investigator, U.S. Department of Energy, $\mathrm{CO}_{2}$ Project, "Response to a tundra ecosystem to elevated atmospheric carbon dioxide and $\mathrm{CO}_{2}$-induced climate change."

Principal Investigator, National Science Foundation, "Mechanisms controlling resource use, community organization, and succession in fire-dominated chaparral ecosystems."

Principal Investigator, Principal Scientist, U.S. Department of Energy. DOE $R^{4} D$ Program: "Effect of perturbation of tundra drainage systems on ecosystem dynamics of tundra and riparian vegetation."

Principal Investigator, U.S. Department of Energy, $\mathrm{CO}_{2}$ Project, "The response of arctic ecosystems to elevated carbon dioxide regimes."

Principal Investigator, National Science Foundation, "Mechanisms controlling resource use, community organization, and succession in fire-dominated chaparral ecosystems."

Editorial Review Board Member, Tree Physiology

Editorial Board Member, Ecologia Mediterranea

SDSU Representative, Arctic Research Consortium of the U.S. (ARCUS) 


\section{Selected Relevant Publications (from 115 total):}

Moreno, J.M. and W.C. Oechel. Factors controlling postfire seedling establishment in southern California chaparral. Oecologia. (in press).

Oechel, W.C., G. Riechers, W.T. Lawrence, T.I. Prudhomme, and N. Grulke. 1992. ' $\mathrm{CO}_{2}$ LT', an automated, null-balance system for studying the effects of elevated $\mathrm{CO}_{2}$ and global climate change on unmanaged ecosystems. Functional Ecology. 6: 86-100.

Sveinbjornsson, B. and W.C. Oechel. Controls on growth and productivity of bryophytes: Environmental limitations under current and anticipated conditions. In: J.W. Bates and A.M. Farmer (eds.). Bryophytes and Lichens in a Changing Environment. Oxford University Press. (in press).

Shaver, G.R., W.D. Billings, F.S. Chapin, A.E. Giblin, K.J. Nadelhoffer, W.C. Oechel, and E.B. Rastetter. Global change and the carbon balance of arctic ecosystems. BioScience. (in press).

Oechel, W.C. and W.D. Billings. 1992. Effects of global change on carbon balance of arctic plants and ecosystems. In: T. Chapin, R. Jeffries, J. Reynolds, G. Shaver, and J. Svoboda (eds.). Arctic Ecosystems in a Changing Climate. Academic Press. pp. 139167.

Moreno, J.M. and W.C. Oechel. 1991. Fire intensity effects on the germination of shrub and herbaceous species in southern California chaparral. Ecology. 72: 1993-2004.

Swank, S.E. and W.C. Oechel. 1991. Interactions among the effects of herbivory, competition and resource limitation on chaparral herbs. Ecology. 72: 104-115.

Mooney, H.A., B.G. Drake, R.J. Luxmoore, W.C. Oechel, and L.F. Pitelka. 1991. Predicting ecosystem responses to elevated $\mathrm{CO}_{2}$ concentrations. BioScience. 41: 96-104.

Moreno, J.M. and W.C. Oechel. 1991. Fire intensity and herbivory effects on postfire resprouting Adenostoma fasciculatum in southern California chaparral. Oecologia. 85: 429-433.

Van Cleve, K., W.C. Oechel, and J.L. Hom. 1990. Response of black spruce (Picea mariana [Mill] B.S.P.) ecosystems to soil temperature modification in interior Alaska. Canadian Journal of Forest Research. 20: 1530-1535.

Grulke, N.E., G.H. Riechers, W.C. Oechel, U. Hjelm, and C. Jaeger. 1990. Carbon balance in tussock tundra under ambient and elevated atmospheric $\mathrm{CO}_{2}$. Oecologia. 83: 485-494.

Oberbauer, S.F. and W.C. Oechel. 1989. Maximum $\mathrm{CO}_{2}$ assimilation rates of vascular plants on an Alaskan arctic tundra slope. Holarctic Ecology. 12: 312-316.

Oberbauer, S.F., S.J. Hastings, J.L. Beyers, and W.C. Oechel. 1989. Comparative effects of downslope water and nutrition movement on plant nutrition, photosynthesis, and growth in Alaskan tundra. Holarctic Ecology. 12: 324-334.

Oechel, W.C. 1989. Nutrient and water flux in a small arctic watershed: An overview. Holarctic Ecology. 12: 229-237.

Larigauderie, A., D.W. Hilbert, and W.C. Oechel. 1988. Effect of $\mathrm{CO}_{2}$ enrichment and nitrogen availability on resource acquisition and resource allocation processes in a grass, Bromus mollis. Oecologia. 77: 544-549.

Chapin, F.S., W.C. Oechel, K. Van Cleve, and W. Lawrence. 1987. The role of mosses in the phosphorus cycling of an Alaskan black spruce forest. Oecologia. 74: 310-315.

Tissue, D.L. and W.C. Oechel. 1987. Physiological response of Eriophorum vaginatum to field elevated $\mathrm{CO}_{2}$ and temperature in the Alaskan tussock tundra. Ecology. 68: 401-410.

Hilbert, D.W., T.I. Prudhomme, and W.C. Oechel. 1987. Response of tussock tundra to elevated carbon dioxide regimes: Analysis of ecosystem $\mathrm{CO}_{2}$ flux through nonlinear modelling. Oecologia. 75: 466-472.

Oberbauer, S., W.C. Oechel, and G.H. Riechers. 1986. Soil respiration of Alaskan tundra at elevated atmospheric $\mathrm{CO}_{2}$ concentration. Plant and Soil. 46: 145-148.

Oechel, W.C. and K. Van Cleve. 1986. The role of bryophytes in nutrient cycling in the taiga. In: K. Van Cleve, F.S. Chapin II, P.W. Flanagan, L.A. Viereck, and C.T. Dyrness 
(eds.). Forest Ecosystems in the Alaskan Taiga: A Synthesis of Structure and Function, Springer-Verlag, New York. pp. 121-137.

Oechel, W.C. and G.H. Riechers. Impacts of increasing $\mathrm{CO}_{2}$ on natural vegetation, particularly the tundra. Proceedings of Climate-Vegetation Workshop, NASA/Goddard Space Flight Center, Greenbelt, Maryland, January 27-29, 1986. pp. 36-42.

Oechel, W.C. and B. Strain. 1985. Response of native species and ecosystems. In: Direct' Effects of Increasing Carbon Dioxide on Vegetation. Department of Energy DOE/ER0238.

Oechel, W.C. and W.T. Lawrence. 1985. Taiga. In: H. Mooney and B. Chabot (eds.). The Physiological Ecology of North American Vegetation. Chapman and Hall Publishers. pp. 66-94.

Miller, P.C., P.M. Miller, M. Blake-Jacobson, F.S. Chapin III, K.R. Everett, D.W. Hilbert, J. Kummerow, A.E. Linkins, G. M. Marion, W.C. Oechel, S.W. Roberts, and L. Stuart. 1984. Plant-soil processes in Eriophorum vaginatum tussock tundra in Alaska: A systems approach. Ecol. Monogr. 54: 361-405. 


\section{APPENDICES}




\section{APPENDIX I}

List of Publications, Abstracts and Presentations 
Project Abstracts, Publications, and Manuscripts 1990-1992

Abstracts:

W.C. Oechel, M. Jenkins, S.J. Hastings, G. Vourlitis, N. Grulke, and G. Riechers. 1991. Effects of recent predicted global change on arctic ecosystems. Abstract, Bull. Ecol. Soc. 72: 209.

W.C. Oechel, M. Jenkins, S.J. Hastings, G. Vourlitis, and G. Marion. 1991. Recent climate change and interaction with carbon balance of the arctic tundra. Suppl. EOE Transactions. American Geophysical Union. Vol. 72, No. 44, p. 70.

W.C. Oechel. Effects of Global changes on carbon flux and carbon storage in arctic ecosystems. International Symposium on Global Change. Shinjuku, Tokyo, Japan,March 27-29, 1992.

Publications:

N.E. Grulke, G.H. Riechers, W.C. Oechel, U. Hjelm, and C. Jaeger. 1990. Carbon balance in tussock tundra under ambient and elevated atmospheric $\mathrm{CO}_{2}$. Oecologia. 83. 485494.

K. Van Cleve, W.C. Oechel, and J.L. Hom. 1990. Response of black spruce (Picea mariana [Mill] B.S.P.) ecosystems to soil temperature modification in interior Alaska.

Canadian Journal of Forest Research. 20: 1530-1535.

H.A. Mooney, B.G. Drake, R.J. Luxmoore, W.C. Oechel, and L.F. Pitelka. 1991. Predicting ecosystem responses to elevated $\mathrm{CO}_{2}$ concentrations. BioScience. 41: 96-104.

B.R. Strain, L.H. Allen, Jr., D. Baldocchi, F. Bazzaz, J. Burke, R. Dahlman, T. Denmead, G. Hendrey, A. McLeod, J. Melillo, W. Oechel, P. Risser, H. Rogers, J. Rozema, and R. Wright. 1991. Available technologies for field experimentation with elevated $\mathrm{CO}_{2}$ in global change research. In: H.A. Mooney (ed.). Ecosystem Experiments. John Wiley \& Sons Ltd. pp. 245-261.

W.C. Oechel and W.D. Billings. 1992. Effects of global change on the carbon balance of arctic plants and ecosystems. In: T. Chapin, R. Jeffries, J. Reynolds, G. Shaver, and J. Svoboda (eds.). Arctic Physiological Processes in a Changing Climate. Academic Press. pp. 139-167.

W.C. Oechel, G. Riechers, W.T. Lawrence, T.I. Prudhomme, N. Grulke, and S.J. Hastings. 1992. ' $\mathrm{CO}_{2} \mathrm{LT}$ ' an automated, null-balance system for studying the effects of elevated $\mathrm{CO}_{2}$ and global climate change on unmanaged ecosystems. Functional Ecology. 6: 86-100.

G.R. Shaver, W.D. Billings, F.S. Chapin, III. A.E. Giblin, K.J. Nadelhoffer, W.C. Oechel, and E.B. Rastetter. Global change and the carbon balance of arctic ecosystems. BioScience. (in press).

B. Sveinbjornsson and W.C. Oechel. Controls on growth and productivity of bryophytes: Environmental limitations under current and anticipated conditions. In: J.W. Bates and A.M. Farmer (eds.). Bryophytes and Lichens in a Changing Environment. Oxford University Press. (in press). 


\section{Manuscripts:}

G.M. Marion and W.C. Oechel. Holcene carbon balance in arctic Alaska. The Holcene. (submitted).

G.L. Vourlitis, W.C. Oechel, S.J. Hastings, and M.A. Jenkins. The effect of soil moisture and thaw depth on methane flux from wet coastal tundra ecosystem on the north slope of Alaska. Chemosphere. (submitted).

W.C. Oechel, M. Jenkins, S.J. Hastings, G. Riechers, N. Grulke, and G. Vourlitis. The effect of climate change on the carbon balance of arctic tundra ecosystems. Nature. (submitted).

G.L. Vourlitis, W.C. Oechel, S.J. Hastings, and M.A. Jenkins. A system for measuring in situ $\mathrm{CO}_{2}$ and $\mathrm{CH}_{4}$ flux in unmanaged ecosystems: An arctic example. Functional Ecology. (submitted). 
Selected Invited Participation in Project-Related Workshops and Conferences, 1989-1992

Large Scale $\mathrm{CO}_{2}$ Enrichment Workshop. Washington, D.C. 4-6 January, 1989.

"Plant Carbon Balance." International Symposium on the Physiological Ecology of Arctic PlantsImplications for Climate Change. Oakville, Ontario, Canada. 2-6 August, 1989.

"Plant Carbon Balance." 74th Annual Meeting of the Ecological Society of America. Toronto, Ontario, Canada. 6-10 August, 1989.

Intergovernmental Panel on Climate Change Workshop. Woods Hole, Massachusetts. 23-24 October, 1989.

Symposium on Arctic and Global Change. Ottawa, Ontario, Canada. 25-27 October, 1989.

International Symposium on Landscape Ecological Impact of Climate Change. Lunteren, The Netherlands. 3-9 December, 1989.

ARCUS Workshop -- Arctic System Science: A Plan for Action, Boulder, Colorado. 26 February-March 2, 1990.

"Effects of Global Change on Net Ecosystem Carbon Flux of Arctic Tussock Tundra," International Conference on the Role of the Polar Regions in Global Change," Fairbanks, Alaska. 11-15 June, 1990.

"Anticipated Effects of Elevated Atmospheric $\mathrm{CO}_{2}$ and Global Change on Production Fire Frequency and Water Yield of Mediterranean Ecosystems," The Role of Fire in Mediterranean-type Ecosystems, Universidad Internacional Menendez Pelayo, Valencia, Spain. 25-29 June, 1990.

"Effects of Global Change in Atmospheric $\mathrm{CO}_{2}$ and Temperature on the Structure and Function and Development of Arctic Ecosystems," V. International Congress of Ecology, Yokohama, Japan. 23-30 August, 1990.

"The Response of Arctic Ecosystems to Global Change," Symposium on Impact of Change on Natural Ecosystems, Trondheim, Norway. 27-29 November, 1990.

International Tundra Experiment (ITEX) Workshop, W.K. Kellogg Biological Station, Hickory Corners, Michigan. 1-5 December, 1990.

Seminar on "Effects of Global Change on Arctic Ecosystems," University of California, Berkeley, Berkeley, California. 15 March, 1991.

GCTE Focus 1 Workshop on Ecosystem Physiology, Asilomar, California. 5-5 May, 1991.

BOREAL Ecosystem-Atmosphere Study (Boreas) Planning Workshop, Wasakesiu Lake, Saskatchewan, Canada. 12-15 May, 1991.

DOE Carbon Dioxide Program $\mathrm{CO}_{2}$ Workshop on the Response of Vegetation to Elevated Atmospheric $\mathrm{CO}_{2}$ Concentration, Edgewater, Maryland. 30-31 May, 1991. 
Seminar on "Global Change and the Carbon Dynamics of Arctic Tundra." Duke University, Durham, North Carolina. 24 June, 1991.

Ecological Society of America Annual Meeting, San Antonio, Texas. 4-8 August, 1991.

Arctic Research Consortium of the U.S. Panel Discussions. Boulder, Colorado. 23-24 August, 1991.

"Anticipated effects of elevated $\mathrm{CO}_{2}$ and climate change on plant processes and implications for the structure and function of Mediterranean-type ecosystems," MEDECOS VI International

Conference on Mediterranean Climate Ecosystems. Maleme, Crete. 23-27 September, 1991.

Arctic Research Consortium of the U.S. Planning Meeting. Washington, D.C. 28 October, 1991.

Climate Research Needs Workshop. Mohonk Mountain, New York, 19-22 November, 1991.

International Tundra Experiment Workshop, Kalamazoo, Michigan. 23-24 November, 1991.

Institute of Geography Academy of Sciences-SDSU Collaborative Research Global Change

Program Meeting. Moscow, Russia. 2-10 February, 1992.

Arctic Research Consortium of the U.S. Annual Meeting. Washington, D.C. 23-25 March, 1992.

"Effects of Global Changes on Carbon Flux and Carbon Storage in Arctic Ecosystems. International Symposium on Global Change," International Symposium on Global Change.

Shinjuku, Tokyo, Japan. 27-29 March, 1992.

Hearing on Global Change Research: Global Warming and the Biosphere. Washington, D.C. 6 April, 1992.

"Response of Native Plants to Elevated $\mathrm{CO}_{2}$," Third International Workshop on Closed Ecological Systems. Tucson, Arizona. 24-27 April, 1992.

"Anticipated Effects of Elevated Atmospheric $\mathrm{CO}_{2}$ and Climate Change on Plant Processes and Implication for the Structure and Function of Mediterranean-type Ecosystems," Symposium on the Future of Mediterranean Landscapes. Tuscany, Italy. 26 April-May 1, 1992. 


\section{APPENDIX II}

Russian Research Sites and Cooperators 


\section{A. Description of Research Sites and Maps}

\section{Russian Arctic: Taymyr Peninsula}

Research will be conducted on the Taymyr Peninsula in north-central Russia (Figs. 8 and 9). This area is ideal for the research proposed here for several reasons. First, every habitat type found in arctic ecosystems (from arctic desert to southern tundra) is found in the region. Secondly, Russian scientists have worked extensively in this region in the past. Data on vegetation types, soil C stores, and weather are quite complete, so the physical and biological characteristics of the site are well known. Thirdly, Russian scientists have set up base camps at some of the proposed research sites (Pura River, Fig. 9) that are equipped with housing, food and fuel facilities. Finally, transportation can be provided by helicopter and motor boat at significantly lower cost compared to U.S. equivalents.

Research sites on the Tymyr Peninsula are run by the Institute of Far North Agriculture, Siberian Subdivision of the Russian Academy of Sciences, and are supported by Moscow State University. We have established contacts through Moscow State University with Drs. Tagir Gilmanov and Victor Nosov, who are also collaborating scientists in the proposed NSF and DOE research (curricula vitae, Appendix III). There are six possible sites in the region where measurements of $\mathrm{CO}_{2}$ and $\mathrm{CH}_{4}$ flux would be carried out. Various research projects have been conducted at all sites by Russian scientists in the past. The following are the research sites on the Taymyr Peninsula (Fig. 9) that are proposed as a transect to measure carbon flux.

1. Dikson Site $\left(73^{\circ} 30^{\prime} \mathrm{N}, 81^{\circ} 15^{\prime} \mathrm{E}\right)$. This site is located near the town of Dikson and is an example of coastal arctic tundra. Long term climatic data has been collected here since 1916.

2. Mys Khodnoy Site $\left(73^{\circ} 35^{\prime} \mathrm{N}, 85^{\circ} 05^{\prime} \mathrm{E}\right)$. Located $150 \mathrm{~km}$ east of the Dikson Site near the mouth of the Pyasina River, this site provides a second coastal arctic tundra site.

3. Pura Site $\left(72^{\circ} 30^{\prime} \mathrm{N}, 85^{\circ} 40^{\prime} \mathrm{E}\right)$. This site is well supplied with long term information on weather, vegetation, and soil characteristics, and includes most of the relief elements of the Western Taymyr. There are a total of 240 vascular plant species, and 10 main tundra habitat types with widely varying soil moisture, topographical and community characteristics.

4. Ust-Tareya Site $\left(72^{\circ} 40^{\prime} \mathrm{N}, 91^{\circ} 30^{\prime} \mathrm{E}\right)$. This site is similar to the Pura site. It is also well documented with long-term information about vegetation, soil type, and climate.

5. Agapa Site $\left(71^{\circ} 30^{\prime} \mathrm{N}, 85^{\circ} 50^{\prime} \mathrm{E}\right)$. There are well-documented, long-term records and information on soil type, vegetation, and climate for this site. It is at the northern limit of the southern shrub tundra and has 244 species of vascular plants. In addition, there is a soil moisture and tundra habitat gradient that is oriented perpendicular from the Pyasina River which is adjacent to the site.

6. Lake Pyasina Site $\left(70^{\circ} 40^{\prime} \mathrm{N}, 86^{\circ} 40^{\prime} \mathrm{E}\right)$. This site is close to the upper limit of forest tundra, with similarities to the Agapa site. 


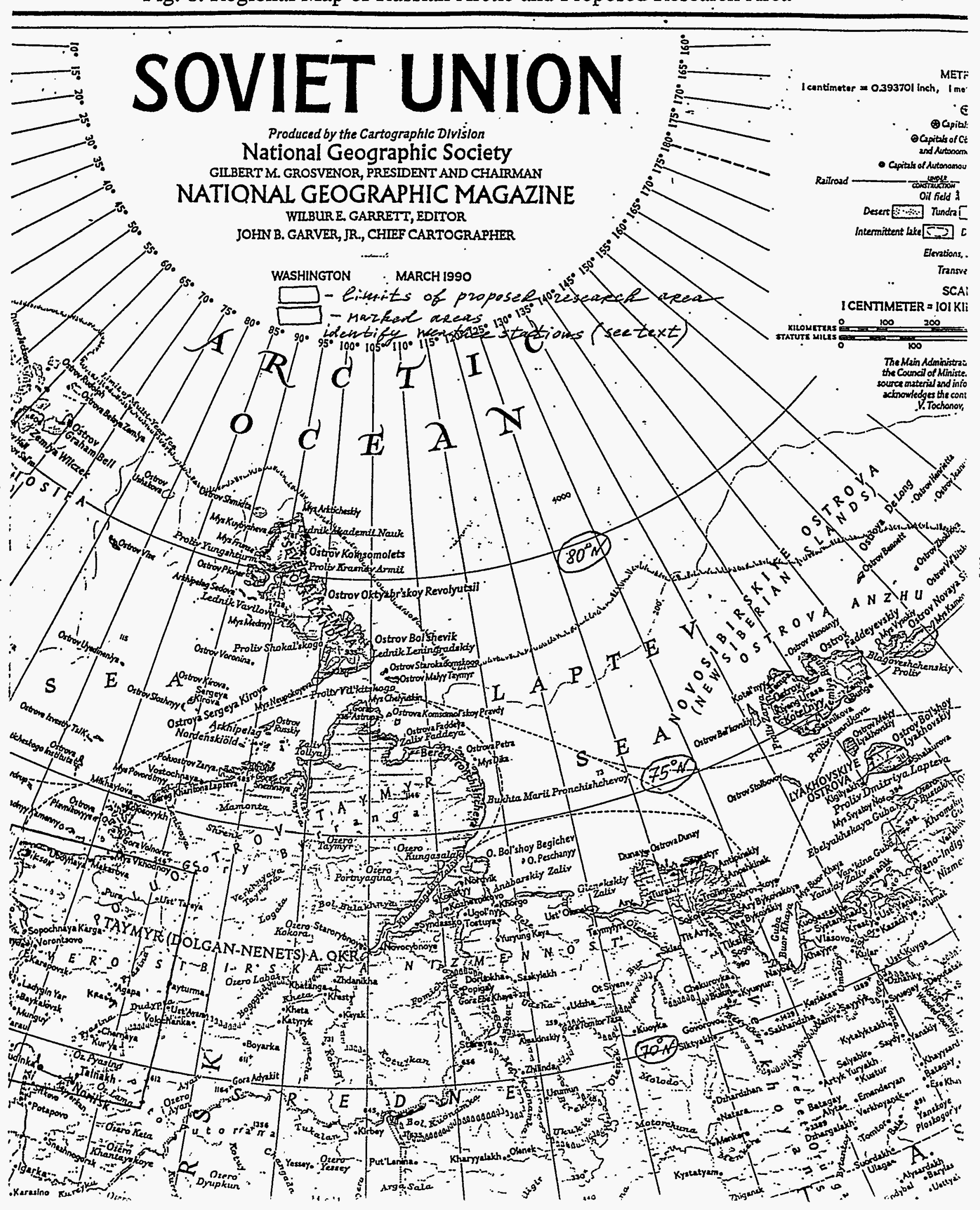


Fig. 9. Proposed Research Site Locations on the Taymyr Penninsula

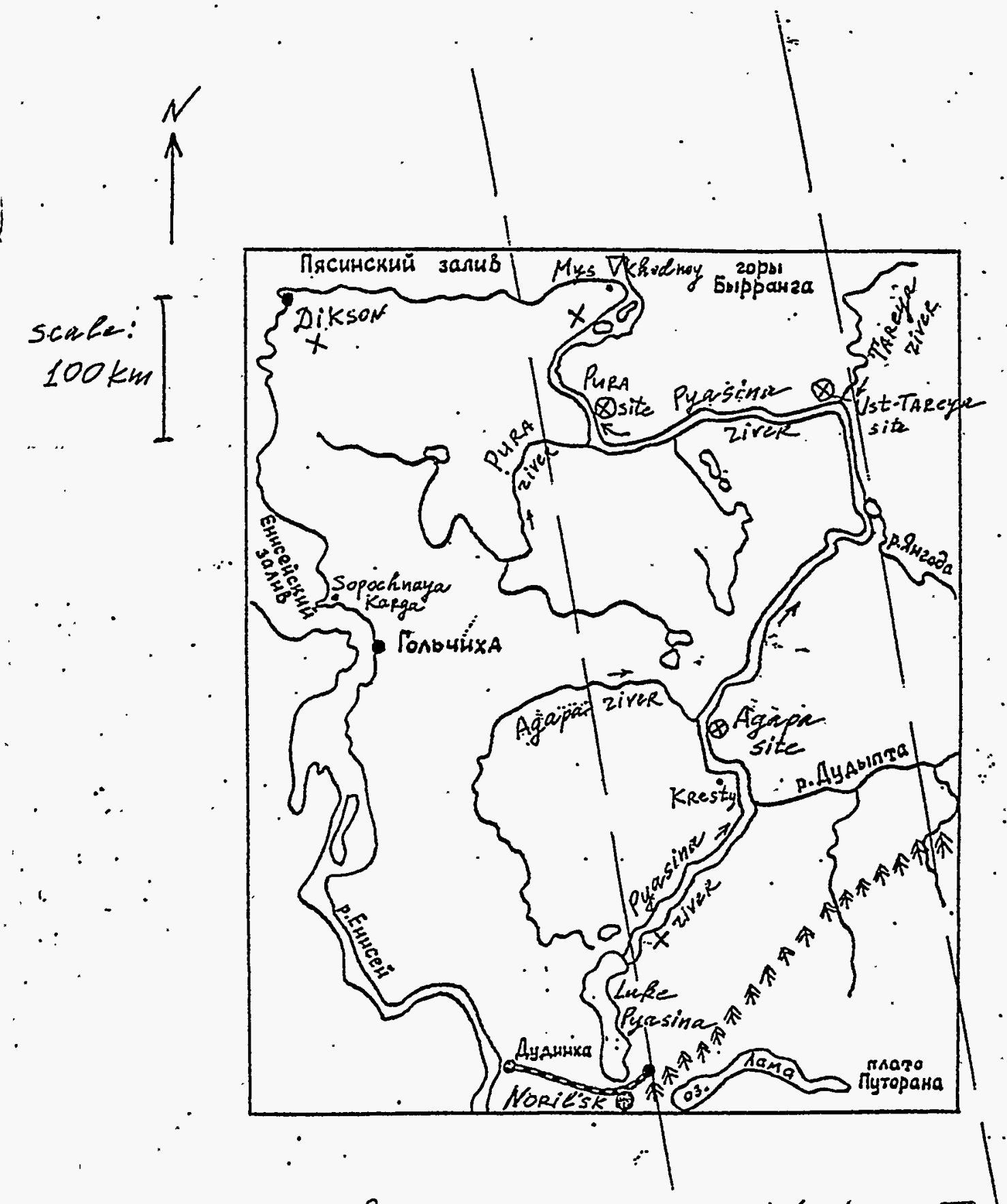

Research area, in Western Thyme (USSR, Russia)

$\otimes$ - oed sites

$x$ - Proposed sites

- limits. of proposed transect

A - north limit of forest tundra zone. 
B. Letter of Support 


\section{Ордена „Знак Почета“}

\section{Научно-исследовательский институт \\ сельского хозяйства Крайнего Севера}

663302 r. Норнльск, ул. Коцсомольская, 1. Телеграфный адрес: Норндьск, Полярное земледелие. Тезефон оо̆щий 4-20-58

\section{7th \\ Ref. No $192 / 1$}

Prof. Walter C. Dechel

Department of Biology

San Diego State University

San Diego, USA

Dear Mr. Dechel:

Re: Estimation of expenditures for the joint expedition.

In compliance with the agreement we reached during our meeting on February 3, 1992 in the Moscow State University on the joint expedition scheduled for July this year to be made in the Pura river region (Taimyr area), I have a pleasure in informing You of the tentative expenditures of the American Side to be born.

- The following calculation is made supposing that there will be 3 persons from the American Side participating in the said expedition.

1. Operation of a helicopter ( 50 hours of work) may cost us 6,000 (Six thousand US \$). HCwever, by JuIy 1992 the the Aeroflot company may increase the rent . . cost by 50 per cent.

2. Hotel accomodation for 3 persons in Moscow and Norilsk may totally reach 3,000 US\$ ( USD Three thousand).

3. Purchasing scme food-stuffs in Norilsk may amount to USD 1,000 (One thousandy. 4. Miscellaneous other other expenditures, which may occur, we think may amount to also USD 1,000 .

Furthermore, the American Side should, transfer on the current account No 389101 in the Norilsk branch of the Uncombank 700p00Roubles on arrival to Norilsk to cover some part of the Institute's expenditures related to the expedition carrying out.

If the above conditions suit You, we shall sign an Agreement between the University and the Institute by April 1992.

I hope to hear from you soon. Thank You.

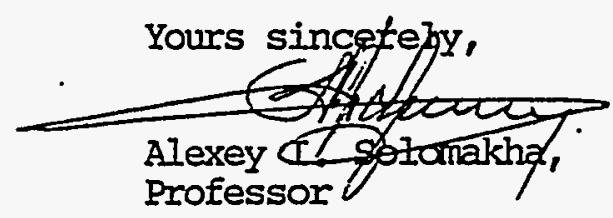




\section{GIS Data Base for Taymyr Peninsula}

The information that follows includes:

1. IDRISI made map of the Taymyr Peninsula that includes key landscape types produced by Dr. Tagir Gilmanov's group at the University of Moscow.

2. Landscape, Vegetation and Soils maps of the Taymyr Peninsula produced by Dr. Roman Zlotin's group at the Institute of Geography of Russian Academey of Sciences. A legend for Soils is presently being translated into English.

3. Reduced (75\%) color (copied in black and white) satellite images of the Pyasina River basin which form a four-part composite picture in the order of NW, SW, $\mathrm{NE}, \mathrm{SE}$.

4. GIS capabilities of the Institute of Geography of Russian Academy of Sciences. 


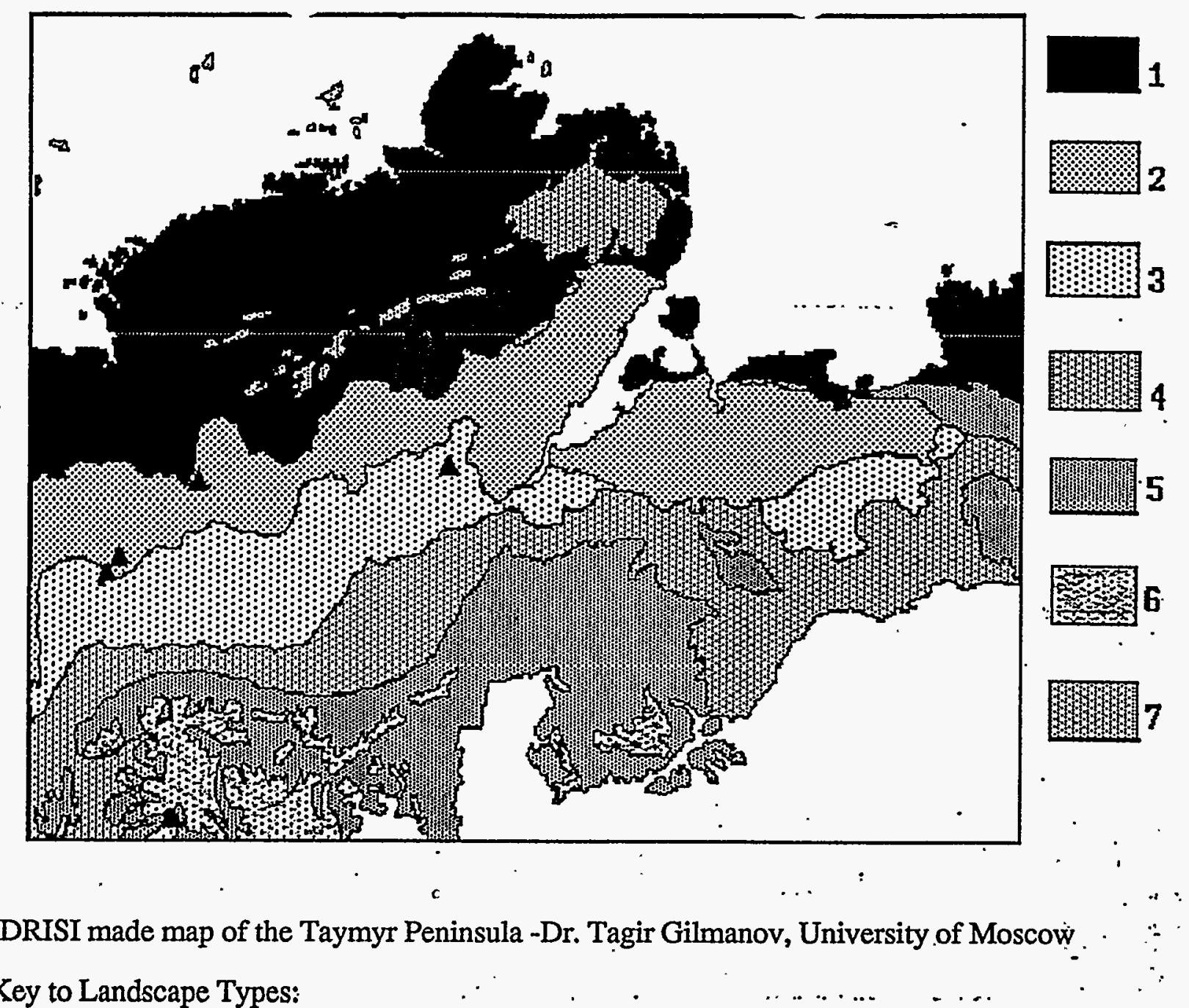

$\therefore$ IDRISI made map of the Taymyr Peninsula -Dr. Tagir Gilmanov, University of Moscow 궁․․

1- Arctic tundra

2- Subarctic (typical) tundra

3- Subarctic southern tundra

4- Forest tundra

5- Mountain tundra

6- Boreal mountain stony desert

7- Subarctic mountain polar desert 


\section{Legends}

Map of Landscapes, 1988 (1:4000000)

3a -tundra lowlands

$3 \mathrm{~b} \quad$-tundra uplands

4a -European typical tundra lowlands

$4 \mathrm{~b} \quad$-European typical tundra uplands

5a -European southern tundra lowlands

5b -European southern tundra uplands

41 -mountain tundra and European cold stony deserts

Map of Vegetation, 1990 (1:4000000)

$1 \quad$-polar deserts

$2 \mathrm{~b} \quad$-arctic tundra

$3 b$-northern herbaceous-moss and low-bush-moss tundra

4 -northern low-bush-moss tundra

5a -southern Salix-tundra

7b -southern bush and herbaceous-low-bush-moss tundra

9a -mountain tundra

110a -grass swamps (Carex-Erophorum)

111 -moss swamps 


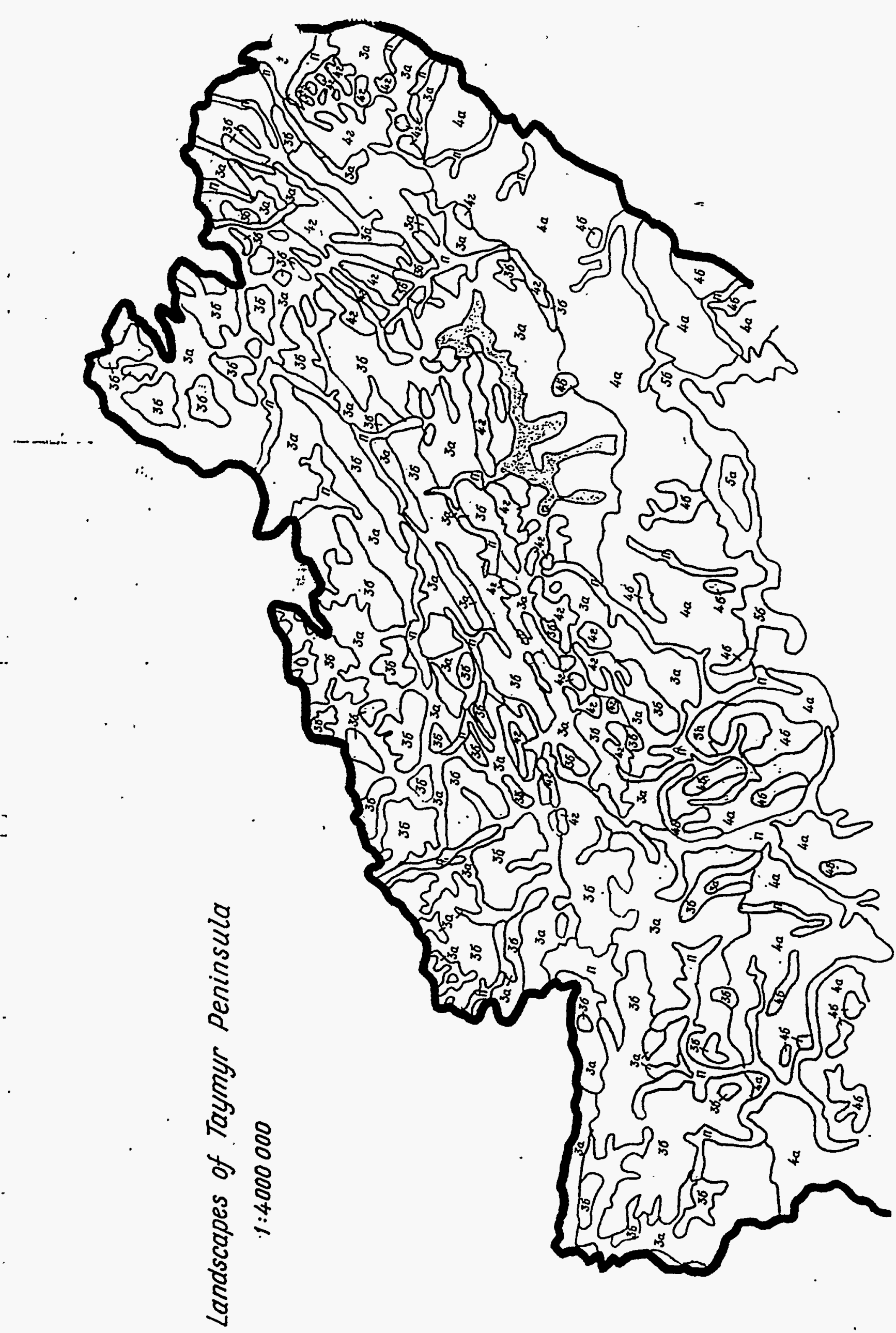




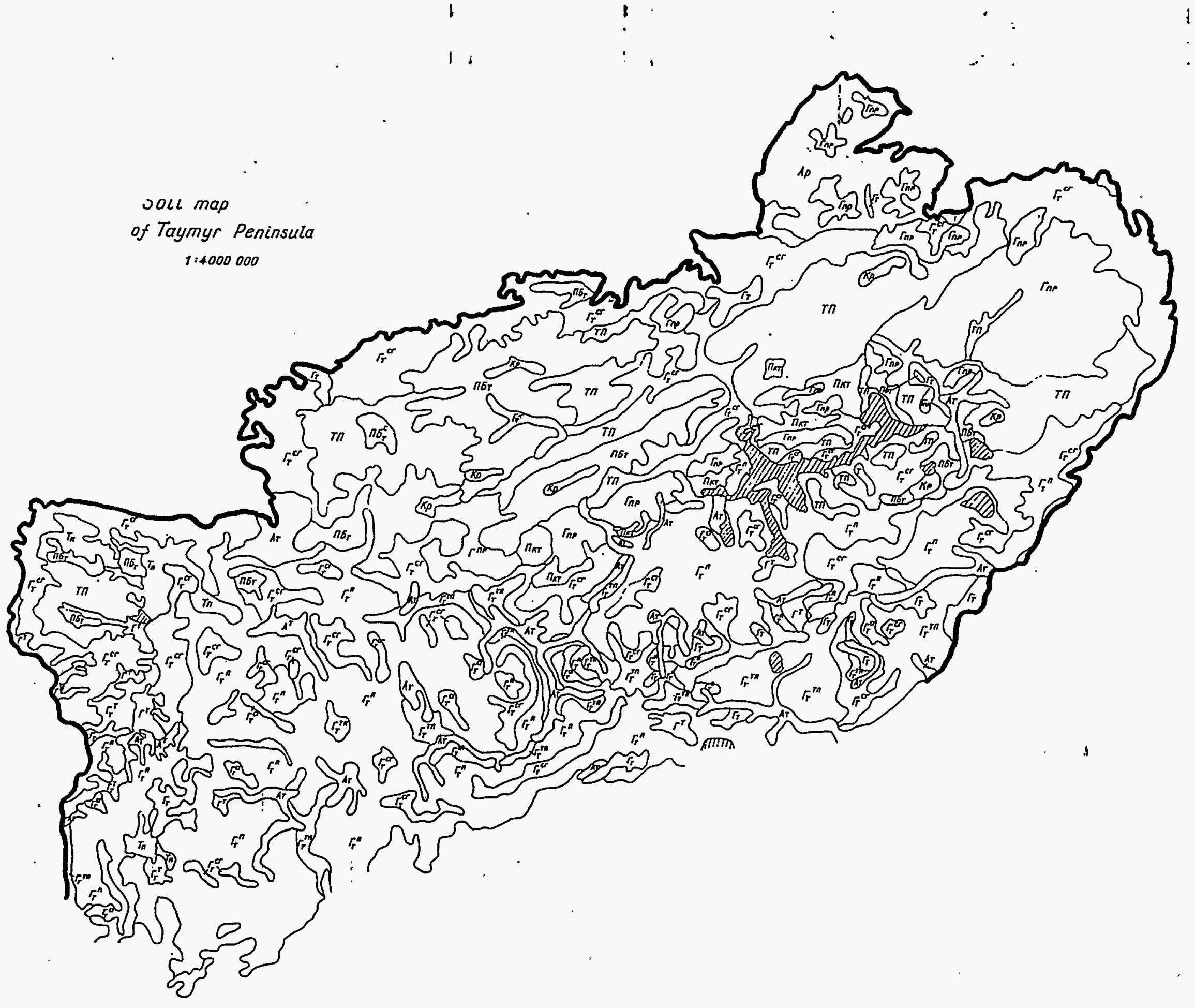



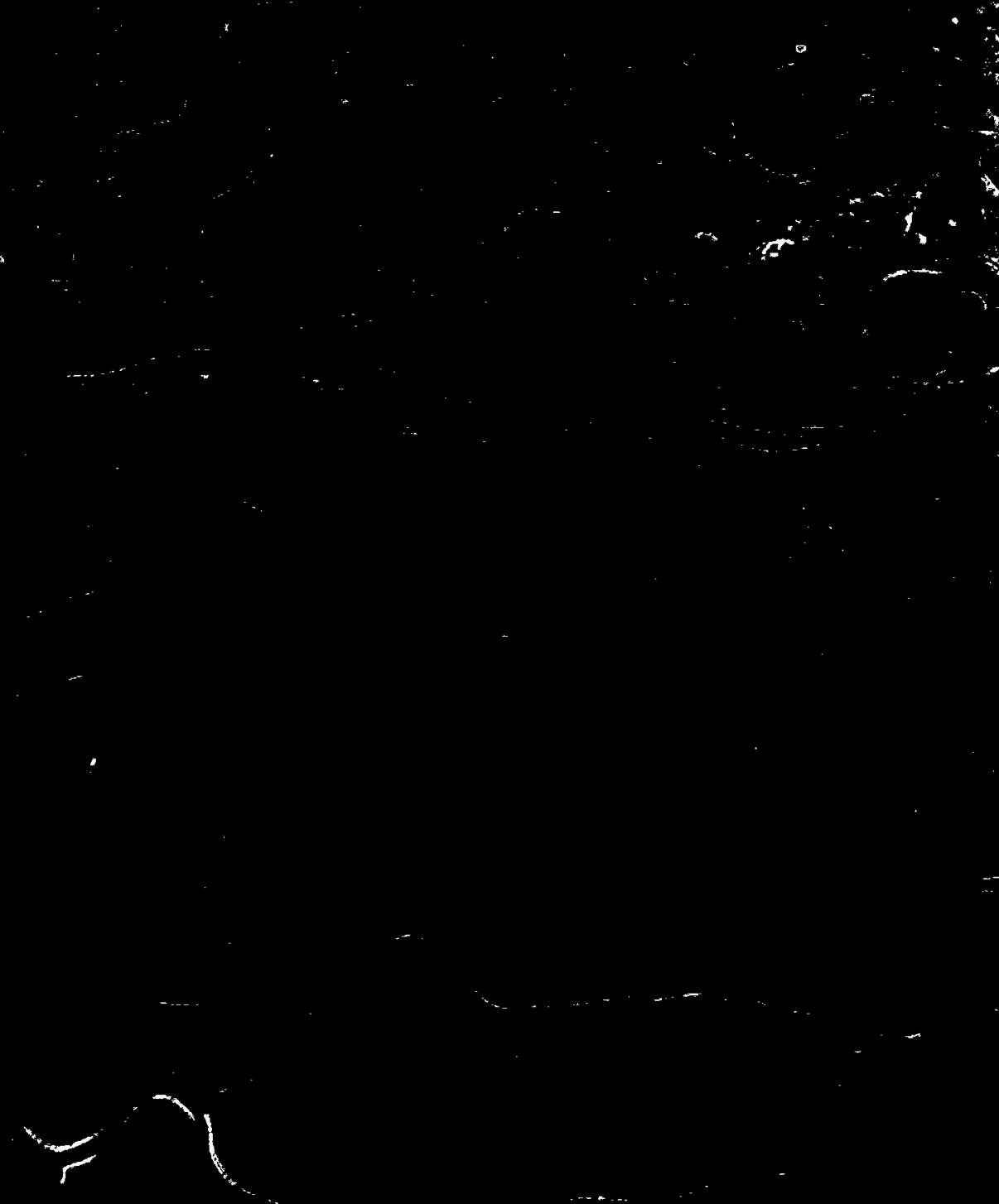


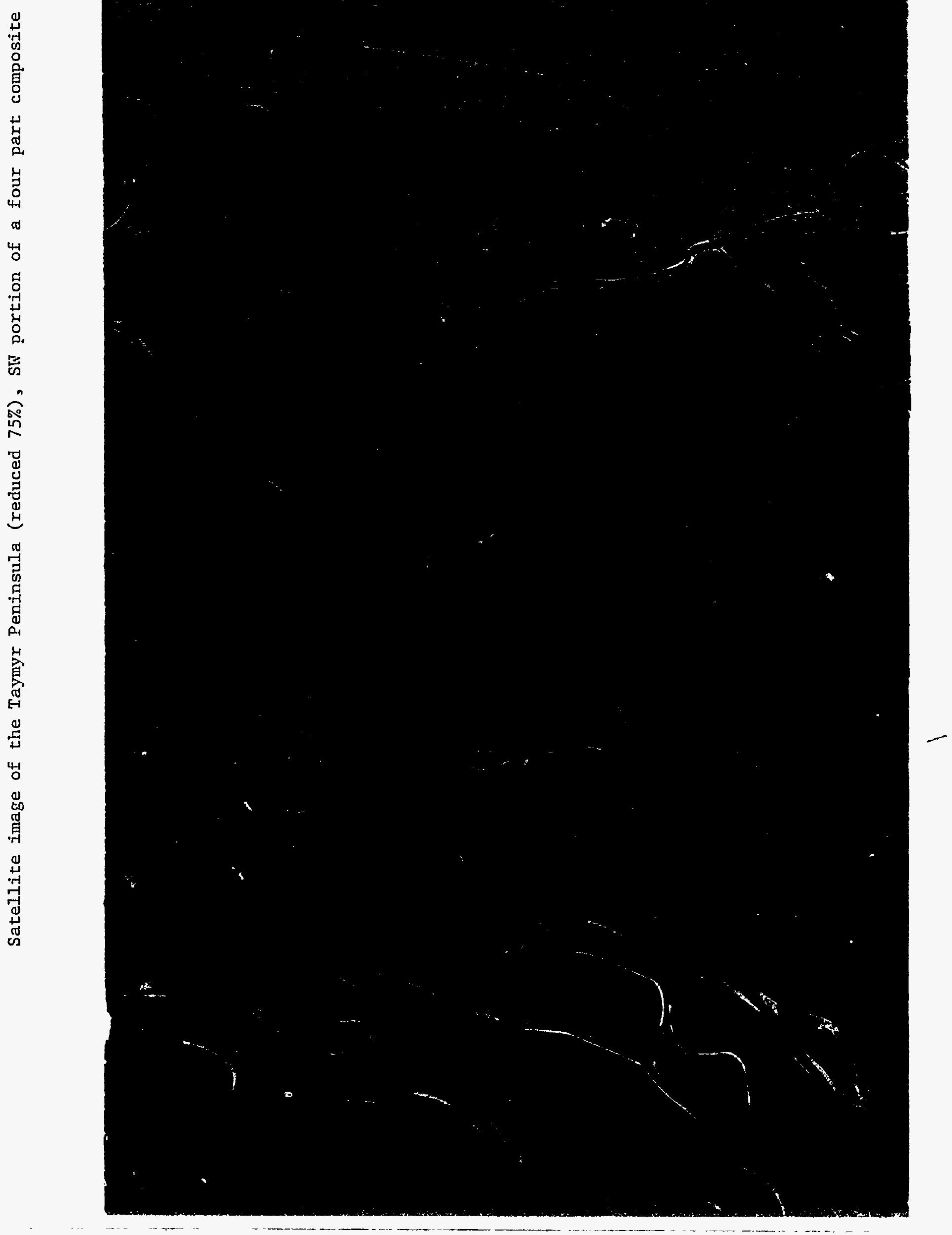




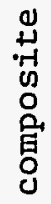

+1
0
0

굴

of

4

도

苔

될

命

ت్d

5

空

롬

넝

a

苛

ब

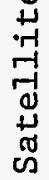

照

.

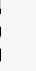

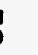

.

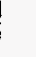

م

$\underset{d}{J}$

氙

这

政

里

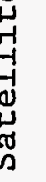




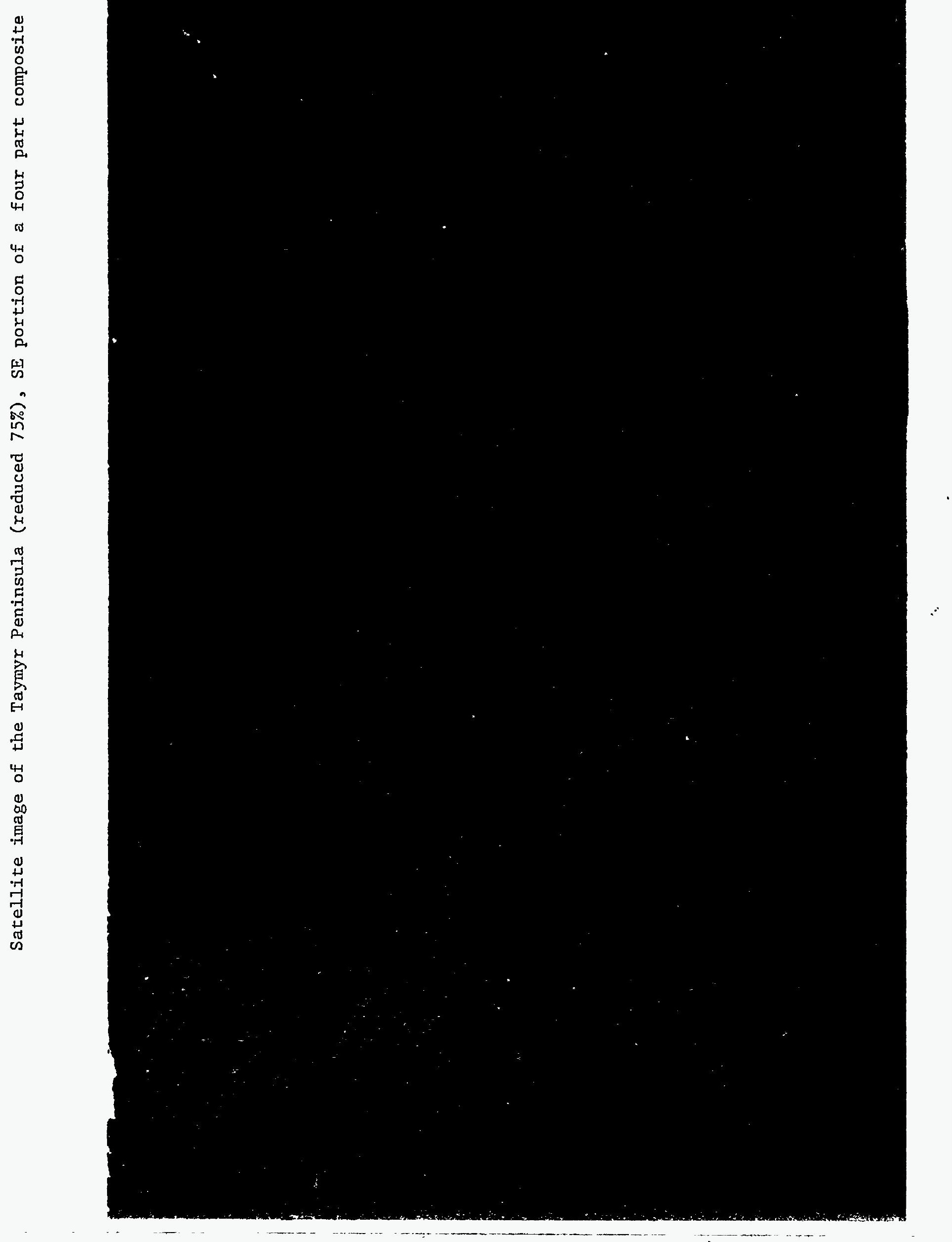




\section{Dear colleague !}

During last years Institute of Geography of the USSR Academy of Sciences designed and used a set of basic GIS functions for electronic mapping (see below). Now we are interested to continue this direction in more close contacts with foreign colleagues. We would like to take part in your own or joint GIS projects, especially in the following aspects:

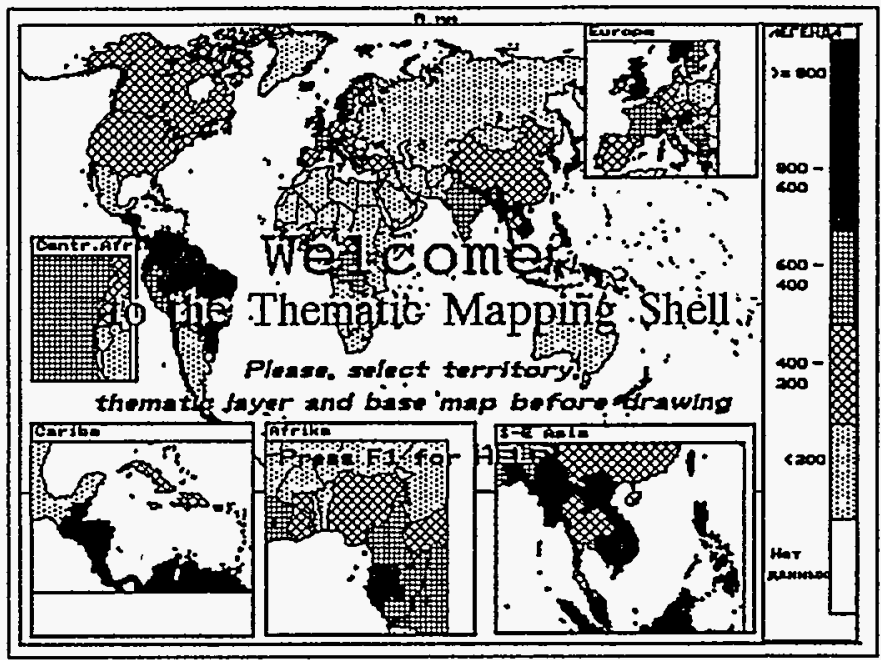

- creation of spatial and thematic data bases (including digitizing sets of maps, editing, creation multi-layer structure of maps, converting to different formats and projections);

- design of electronic atlases (databases and software) for wide range of users ( for research or educational purposes);

- design the software for GIS ( on the base of your orders and our abilities).

We have an experience in design and use of our own software (on base of $C$ language and Assembler), map digitizing and database creation, use ARC/INFO (our Institute has got the rights for the distribution of ARC/INFO in the USSR and Russia from ESRI last year), IDRISI, EPPL7 and some others GIS and mapping systems for microcomputers. We use mainly IBM PC AT $/ 286 / 386$ or PS $/ 2$ compatibles under MS DOS, but it will be possible to realize our technology for graphic stations during the short time, if it will be necessary. We have shown our results to our colleagues from USA, Germany, Austria and other countries and in some relations it was highly estimated. Pictures represent some examples from our software and data sets.

We can offer you the following directions of our work, which can be interested for collaborative projects:

1) map digitizing; we are ready to take part in digitizing of large sets of maps; we can use for this purpose our own well-tested vector graphic editor or ARC/INFO and support high-quality maps and multi-layer structure of maps for electronic atlases; the price of digitizing is 5-10 times lesser then in other developed countries, performance and quality is related to the level of western digital maps;

2) set of our own software functions:

- vector editors for map digitizing (drivers for any digitizer may be written during the short time);

- transformation of maps from X,Y coordinates to geographical coordinates, opposite transformation and from one projection to another; we support more then 30 types of map 


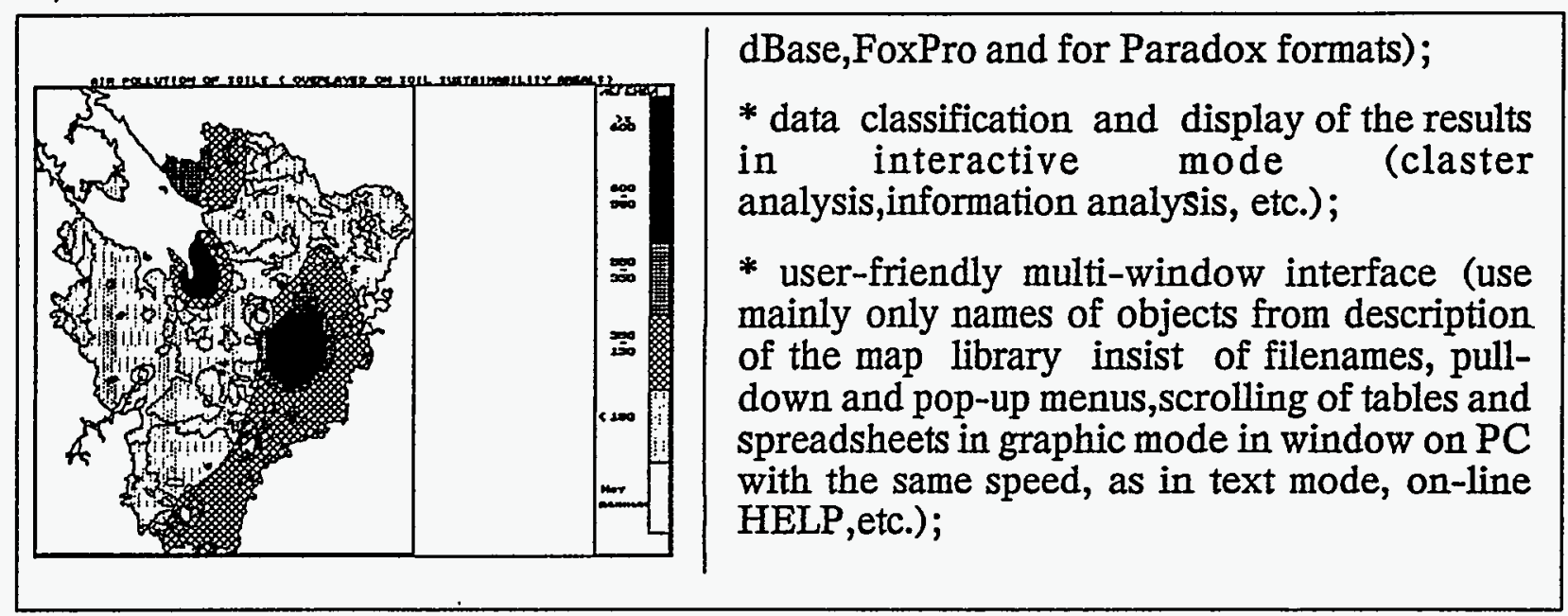

- hard copy output for 9-pin , 24-pin printers, HP Laser Jet or, additionally, any other printer; HPGL plotters;

- any European language may be supported for user interface, dialogue and descriptions.

On the base of mentioned tools we can design and develop the software for your own set of application tasks, including your 'fim mark', with the set of functions on the level of Atlas*Graphics (Atlas*GIS) or MapInfo for PC example.

We have very good specialists in geography, cartography, software design. Price of the similar work and GIS projects in the most part of foreign countries is much higher. Therefore, if we'll begin the joint projects, we have a chance to create database/software products with the set of functions of middle-level commercial products, but on the base of very low expenses. You will can distribute our databases and software among wide range of users ( for students, individual researchers and small groups, for colleagues in undeveloped countries, etc.) due to the low cost, easy-to-use structure and data exchange tools with any other GIS formats.
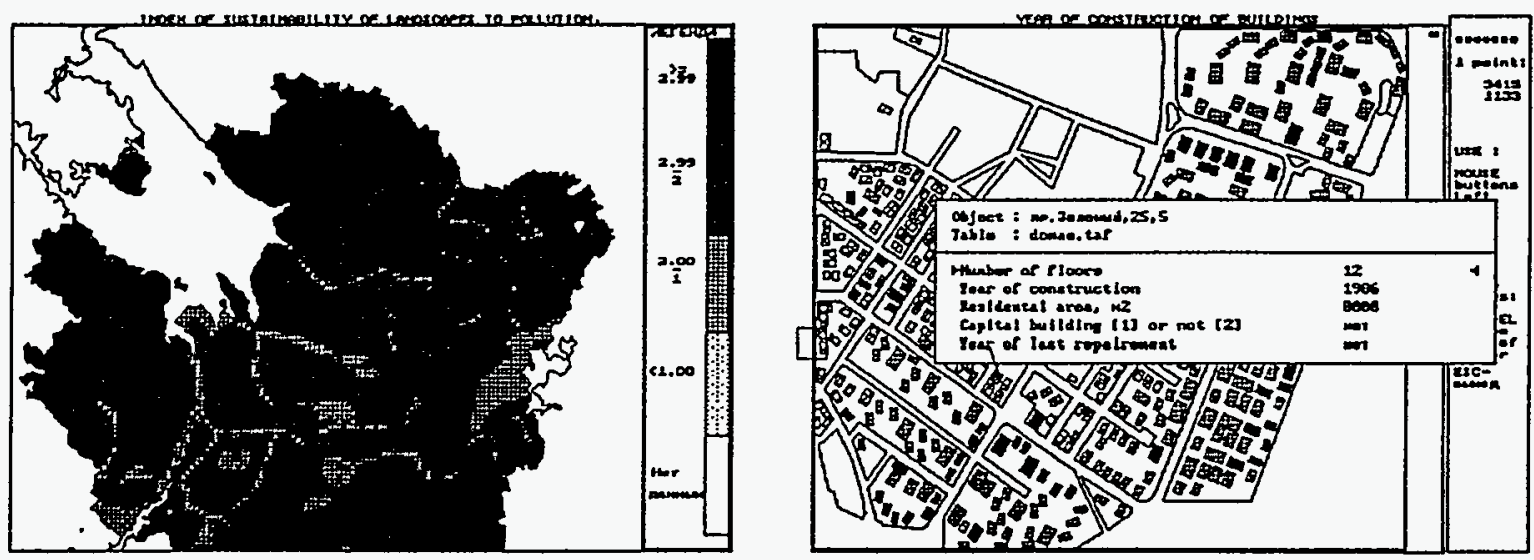

We are ready to collaborate.

\section{CALL US, AND YOU'II HAVE A GOOD CHANCE TO SAVE YOUR MONEY AND TIME!}

\section{FOR CONTACTS CALL:}

Prof. Vladimir Kotlyakov, Institute of Geography of Russian Academy of Sciences,Staromonetny per., 29, Moscow, 109017, Russia

Phone: 238-91-34, Telefax: (095) 2302090 Telex: 411781 Globe SU 
projections, ( the same number as PC ARC/INFO), but including all Soviet projections as well as many western projections; performance of transformation (tested on AT/386/25 MHZ on 1000 points) - our program - from $X, Y$ to GEO coords. - 26-30 sec. (use the least squares method for approximation for high precision) and from GEO to $X, Y-4-5$ sec. (on base of a formula); ARC/INFO transformation - 15 sec. from $X, Y$ to GEO (on base of a formula) and 15 sec. from GEO to $X, Y$ (on base of formula); precision of tramsformation is quite high; measuring of distances and areas on base of GEO coordinates is supported too;

- vector and raster overlay, scrolling large raster imageries on PC display through the screen (including fast display of pixel/by pixel formats like IDRISI);

- transformation of maps to different formats (ARC/INFO, .DXF for AutoCAD, .PCX or other run-lenght encoded formats for raster images, IDRISI pixel/by pixel .IMG format, etc.);

- software shell for creation of programs for the end users, including functions:

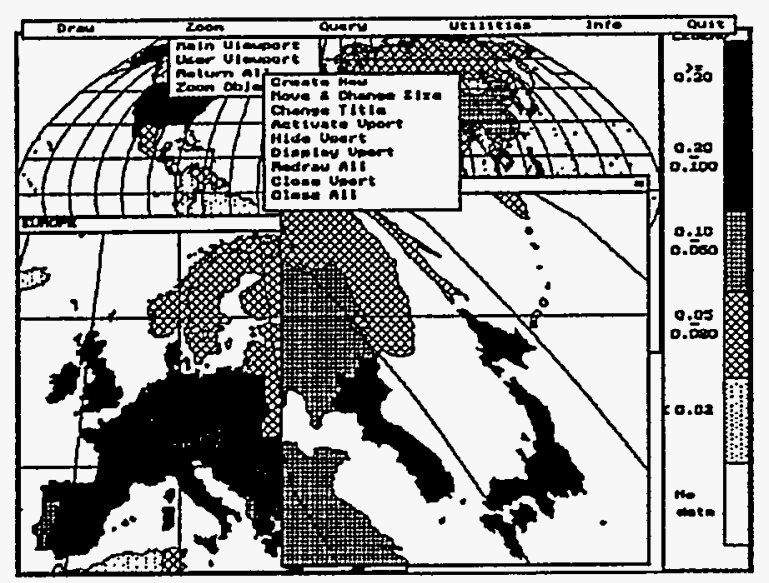

objects like polygons and more then 50000 points on PC, including vector/raster transformation);

* overlapping maps from existing multilayer structure on screen;

* use and managing the system of viewports (windows) to represent maps on screen (you can create, move, change size, change status, hide, close such viewports very fast and without Windows);

Average underground waterflow, $\mathrm{mm}$

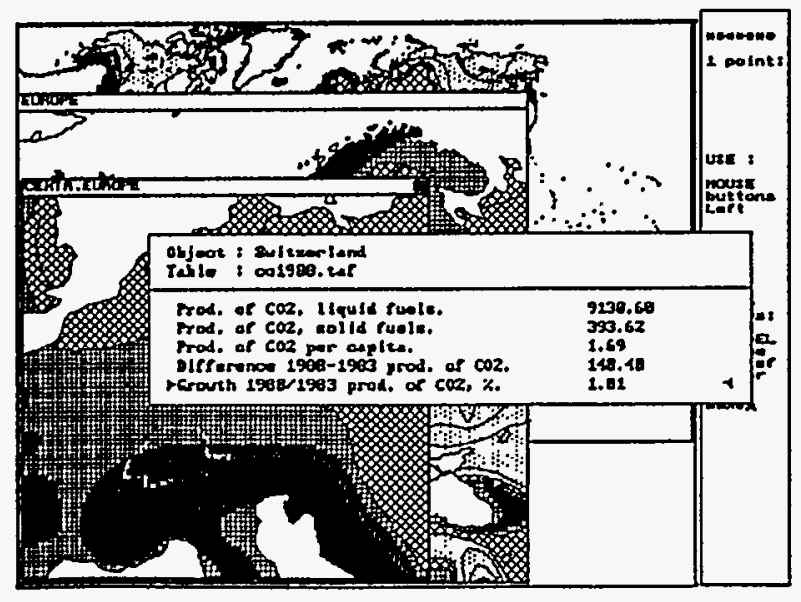

* creation and managing of hierarchical structures of territories, thematic layers, maps and related attribute tables, libraries of maps on the base of our "map tree editor" ;

* original tools for legend design (use of uncorrect graphic variables for representing thematic relations is prevented);

* fast thematic mapping on screen (several seconds for map regeneration with 1000

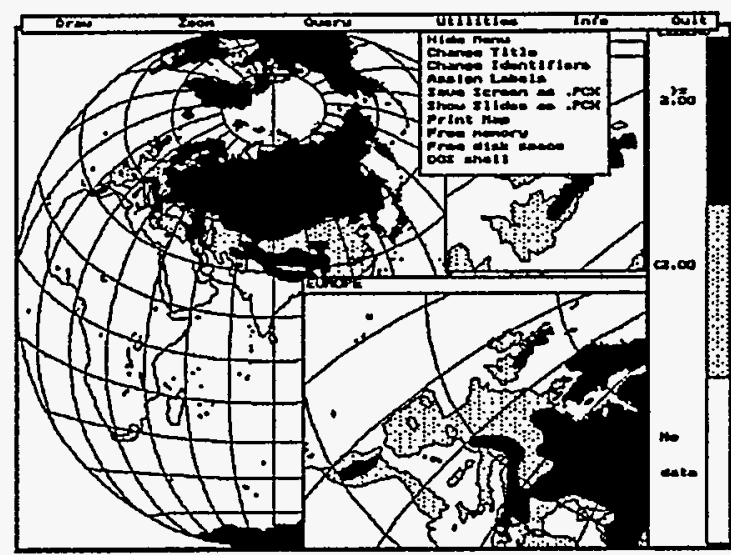

* queries to any objects from any of existing (not necessary displayed) maps from the multi-layer structure;

* get base map scale and current display scale for any viewport,measure the distance between two points, selected by cursor, with high precision;

* map interface between spatially referenced attribute data bases and spatial data sets for public domain or low cost information systems for display, search objects and data, queries, etc. (any known format may be supported - we already have such support for .DBF - 